\title{
Soil erosion mapping and severity analysis based on RUSLE model and local perception in the Beshillo Catchment of the Blue Nile Basin, Ethiopia
}

\author{
Asnake Yimam Yesuph ${ }^{1 *}$ and Amare Bantider Dagnew ${ }^{2 *}$
}

\begin{abstract}
Background: Water induced soil erosion is the most prevailing form of land resources deterioration in the highlands of Ethiopia, where huge amount of fertile soil is being lost annually. The purpose of this study was to estimate and map mean annual soil loss rates in the Gedalas watershed of the Blue Nile Basin, Northeastern Ethiopia. The estimation was carried out by using RUSLE model coupled with local perceptions. Soil, land use/cover, DEM, rainfall and support practice data were used as an input parameters. The raster layers were processed to present the required input parameters in ArcGIS platform and finally the inputs were multiplied together to quantify annual average soil loss rate and generate intensity maps of the watershed.
\end{abstract}

Results: The estimated annual mean soil loss rate of the watershed was found to be $37 \mathrm{tha}^{-1}$ year $^{-1}$, which is more than two times higher as compared to the maximum tolerable soil loss value $\left(16 \mathrm{t} \mathrm{ha}^{-1} \mathrm{year}^{-1}\right)$ and the annual erosion rates range from 0 to above 935 ton $\mathrm{ha}^{-1}$ year $^{-1}$. The annual mean soil loss values below 5 ton $\mathrm{ha}^{-1} \mathrm{year}^{-1}$ were rated as very slight, while those above 50 ton ha $^{-1}$ year $^{-1}$ were categorized as very severe soil erosion risk. Areas experiencing values between these two were further classified into slight, moderate, and severe erosion zones. Soil loss in more than 1/3rd of the study area (36.4\%) was below moderate $\left(<15 \mathrm{t} \mathrm{ha}^{-1}\right.$ year $\left.{ }^{-1}\right)$. Nearly one-fourth $(25.5 \%)$ of the watershed area experienced moderate (between 15 and 30 ton $\mathrm{t} \mathrm{ha}^{-1}$ year ${ }^{-1}$ ) soil loss values. Only $14 \%$ of the watershed areas were classified under severe to extremely severe $\left(>30 \mathrm{t} \mathrm{ha}^{-1} \mathrm{year}^{-1}\right)$ soil erosion risk zones. While $62 \%$ of the watershed still undergoes from very slight to moderate levels of soil loss, yet $72.6 \%$ of soil erosion occurred in zones less than $3200 \mathrm{~m}$ in elevation which represents more than half (51\%) of the total surface area of the watershed. The study also demonstrated that the northeastern parts of the watershed suffer more from high soil erosion risk due to steep slope and rugged landforms of the area. Similarly, $43 \%$ and $35 \%$ of soil erosion occurred on cropland and grasslands areas, respectively.

Conclusion: The quantitative soil loss estimation results and farmers' perception of soil erosion revealed that soil erosion has still remained significant problems in the watershed. The results underscore the urgent need for comprehensive and site-specific SLM practices in the watershed.

Keywords: Gedalas watershed, Soil loss, RUSLE, Erodibility, Erosivity, Perception

\footnotetext{
*Correspondence: asbruzed@yahoo.com; amare_zerfe@yahoo.com

${ }^{1}$ Department of Geography and Environmental Studies, Dilla University,

P. O. Box 419, Dilla, Ethiopia

${ }^{2}$ College of Development Studies, Center for Food Security Studies;

Water and Land Resources Center, Addis Ababa University, P. O. Box 117,

Addis Ababa, Ethiopia
} 


\section{Background}

Soil is the most crucial but highly vulnerable natural resource in the world (Lal 1994; Oldeman et al. 1995; Lal 2001). Soil erosion is a multifaceted and predominant global land degradation process which leads to decline in ecosystem services and functions (Gebrehiwot et al. 2014; Adimassu et al. 2014; Angassa 2014; Haregeweyn et al. 2015). At the global level, the largest share of soil deterioration is caused by water induced soil erosion (Brady and Weil 2012; Hurni 2002; Piccarreta et al. 2006; Rodrigo et al. 2015). It is reported that more than $2 / 3 \mathrm{rd}$ of farmland degradation in Africa is caused by soil erosion (Tully et al. 2015).

Soil erosion not only descent soil quality and productivity due to its on-site impacts (Lal 2001; Nyssen et al. 2004; Pimentel 2006; Haregeweyn et al. 2008; Tamene et al. 2008; Erkossa et al. 2015) but also has far reaching off-site impacts such as destruction of infrastructures, deposition of sediments and associated diversion of streams courses, and pollution of downstream and ground water resources (Tamene et al. 2011; Balthazar et al. 2013; Haregeweyn et al. 2015, 2017).

Erosion-caused land degradations are most popular problems in the highlands of Ethiopia, where huge amount of fertile soil is being lost annually (Hurni 1993; Betrie et al. 2011; Mekonnen et al. 2015; Gessesse et al. 2016). It is one of the many factors affecting rural livelihoods, land productivity and sustainability as it reduces the productive capacity of the land and exacerbates poverty and food insecurity (Lal 2001; Adimassu et al. 2014; Angassa 2014; Erkossa et al. 2015; Gessesse et al. 2015).

Though the risk of soil erosion and sediment yields vary from place to place, the course of actions are generally controlled by a number of environmental (e.g. Landforms; soil characteristics; rainfall amount, intensity and distribution; vegetation type and cover; lithology) and socio-economic attributes such as implementation of anti-erosive land use and management practices (Amare 2007; Bewket 2007).

On the highlands of Ethiopian, there are a number research report pertaining to the peril of soil erosion at various spatial and temporal scales (Hurni 1993, 1996; Sonneveld and Keyzer 2003; Nyssen et al. 2005; Amsalu et al. 2007; Amare 2007; Nyssen et al. 2009; Haregeweyn et al. 2013; Erkossa et al. 2015; Gelagay 2016; Haregeweyn et al. 2017). All these highlighted that erosion-caused land degradations are by far the major problems, which deprive soil's fertility, water holding capacity, and its biodiversity (Hurni 1988; Bewket and Teferi 2009; Gebrehiwot et al. 2014; Fenta et al. 2016; Haregeweyn et al. 2017). However, the extent and magnitude varies from one part of the country to another depending on the farming practices, population pressure, type and susceptibility of the soils to erosion, local climate, the general terrain configurations, and variations in agroecological setting of the area (Tebebu et al. 2010; Monsieurs et al. 2015). All this implies that location specific soil erosion studies are still substantial in Ethiopia for arresting the problem of soil loss.

The present research was undertaken in relatively little known but highly susceptible and fragile areas of the Gedalas Watershed, where soil erosion is the major challenges and common phenomenon, yet such studies are rare. The watershed is more prone to water induced soil erosion and associated land degradation due to multiple causal factors including, but not limited to, the nature of landforms which is manifested by steep slopes, rugged terrains, and complex ravine networks; climate (e.g., erosive rainfall after long period of dry seasons); inappropriate land use/management practices and inherent properties of the soil; and other anthropogenic activities.

It is argued that prior assessment of the spatial distribution of soil erosion is crucial for planning successful sustainable land management program. Hence, evaluation of soil loss rates and identification of erosion prone areas in such an overlooked place is very important to protect the area from further damage. Moreover, successful conservation planning and associated land management strategies requires site-specific, accurate and detailed environmental (e.g. trends and status of soil erosion) and socio-economic information complement by practical experiences of land users and experts. Therefore, this study intends to estimate the current status of soil erosion and develop soil erosion severity map using remote sensing data and local perceptions for optimal soil conservation planning and sustainable land management strategies.

\section{Methods}

\section{The study area}

This study was conducted in Gedalas watershed, which is situated in degraded but relatively in accessible and drought prone areas of the Beshillo Catchment (Tributary of Blue Nile Basin), Northeastern Highlands of Ethiopia. Geographically, it lies between $10^{\circ} 56^{\prime} 52^{\prime \prime}$ and $11^{\circ} 13^{\prime} 26^{\prime \prime} \mathrm{N}$, and $39^{\circ} 06^{\prime} 10^{\prime \prime}$ and $39^{\circ} 18^{\prime} 53^{\prime \prime} \mathrm{E}$ (Fig. 1). The total area of the watershed is $23,970 \mathrm{ha}\left(237.9 \mathrm{~km}^{2}\right)$.

Most of the terrains configurations of the watershed are complex which are evidenced by rugged and strongly dissected mountainous landscapes with steep slopes, deep ravines, multiple small sub catchments and numerous flow routings that aggravate the risks of water induced soil erosion mainly at the rainy seasons. The elevation of the watershed differs over short distances and ranges from 1919 to $4233 \mathrm{~m}$ a.m.s.l with the mean elevation of $3163 \mathrm{~m}$. The slope of the watershed varies from almost 


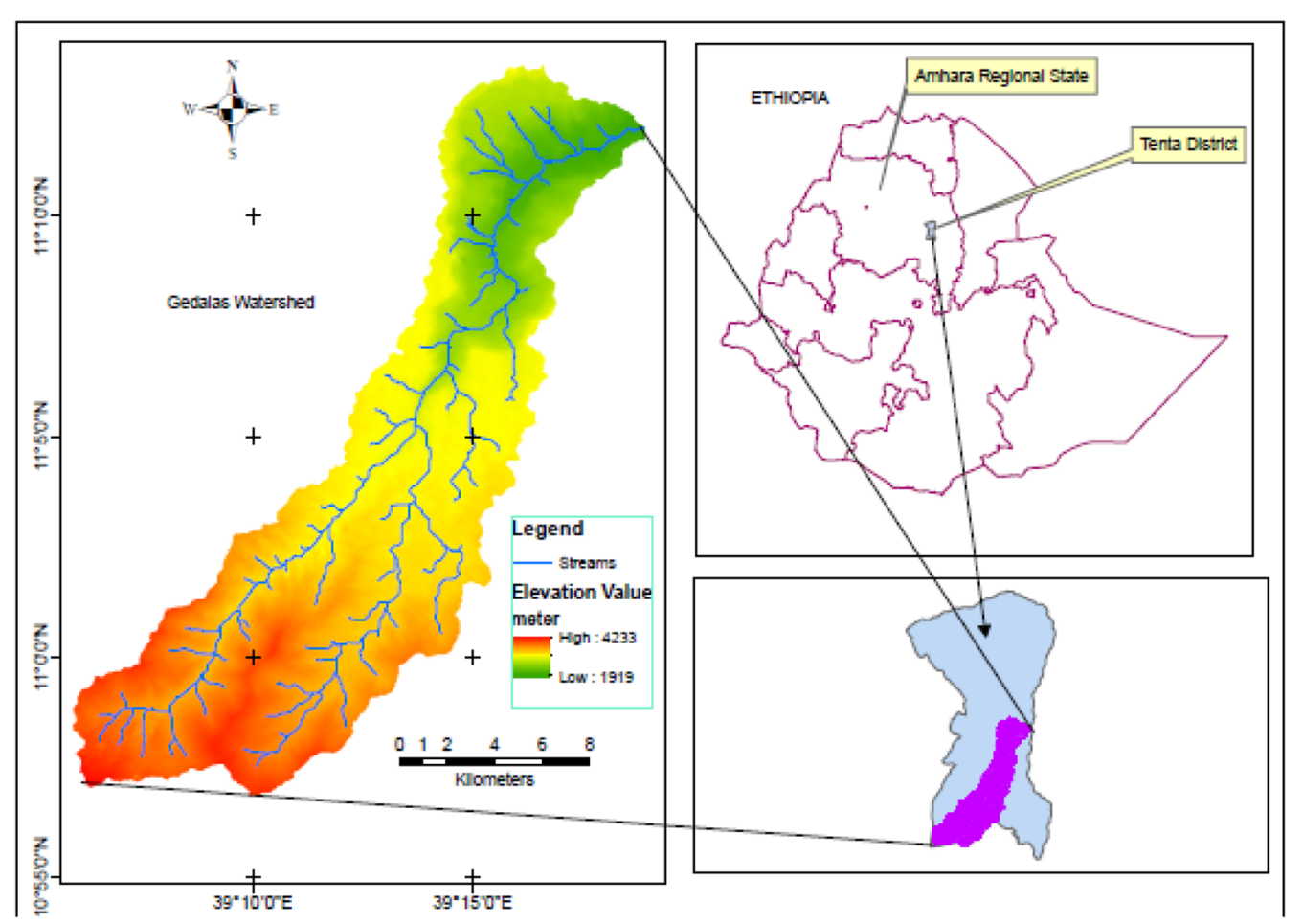

Fig. 1 Location of Gedalas watershed in relation to Ethiopia and the Amhara region

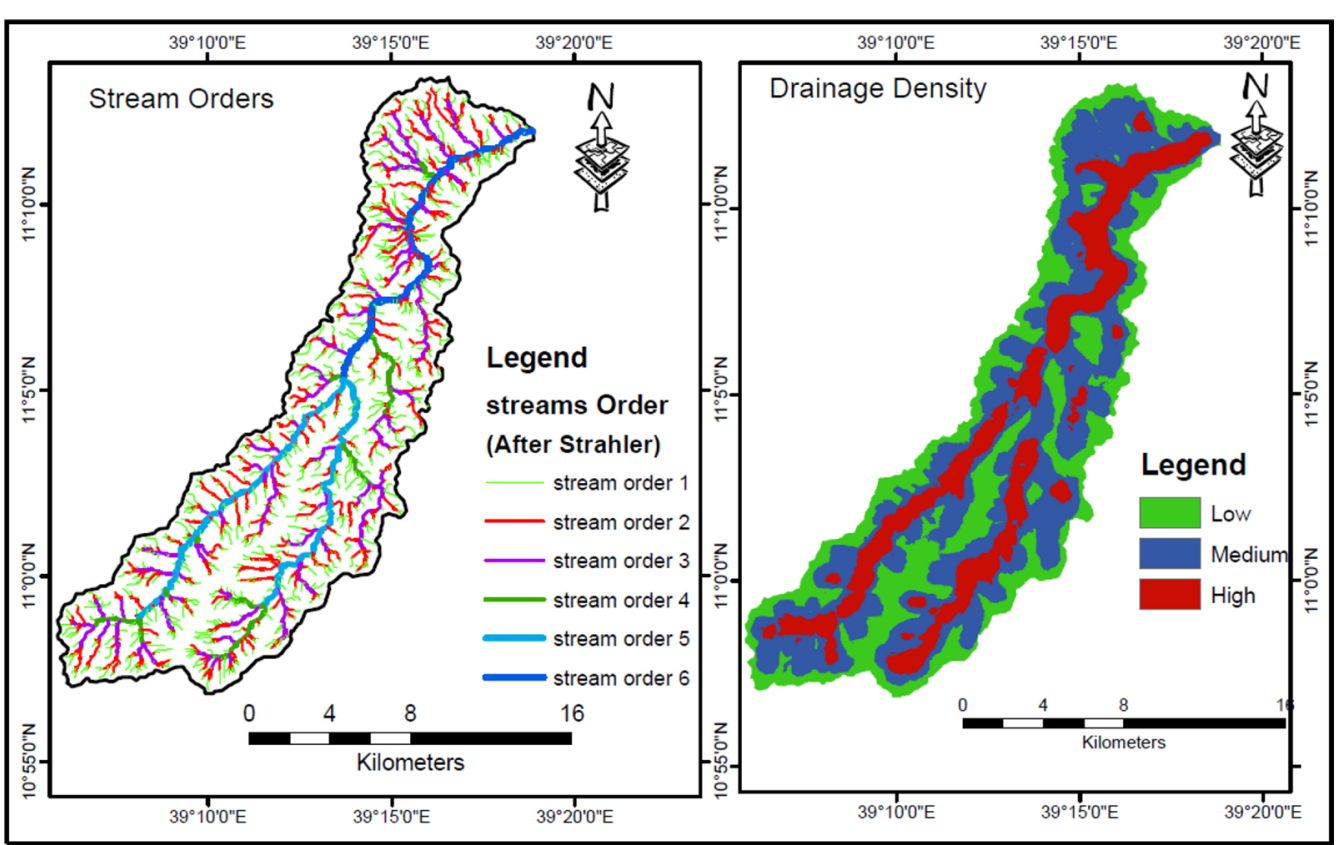

Fig. 2 Stream orders and drainage density of the Gedalas watershed

flat to very steep slopes and steadily decreases northeast wards. The watershed is drained by numerous small streams which generally join and flow to Adela through Gedalas River (Figs. 1, 2).
The watershed falls within three agro-ecological zones (Fig. 3): Temperate (Woina Dega), cool (Dega) and Wurch (Afro alpine) zone (MOA 1998). The pattern of rainfall in watershed is bimodal type with a 30 years mean yearly 


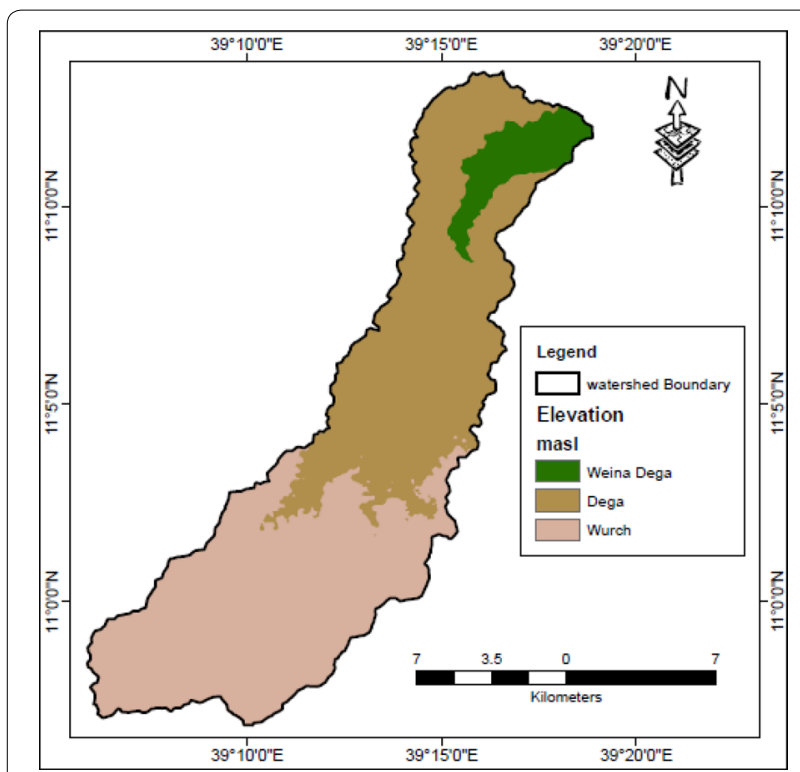

Fig. 3 Agro ecological belts of the Gedalas watershed

rainfall of $930 \mathrm{~mm}$. The highest average monthly rainfall $(303 \mathrm{~mm})$ was recorded in July; the lowest $(10 \mathrm{~mm})$ in December. The rainfall is variable from year to year, in terms of both intensity and distribution. The coefficient of variation of rainfall was calculated at $14.62 \%$ and standardize Rainfall Anomaly index also shows variation over the period of observation which implying that there is inter annual rainfall variability in the area (Fig. 4). The monthly average minimum temperatures ranges between 6.4 and $8.6^{\circ} \mathrm{C}$ while the maximum stretches between 17.9 and $21{ }^{\circ} \mathrm{C}$. The annual mean temperature of the watershed is $13.6^{\circ} \mathrm{C}$ (Fig. 5).
Although there are diverse topographic, agro-ecological zones, soil types, and climatic features, the vegetation cover of the watershed is very poor. However, still there are various types of vegetation types which range from scattered woodlots to Afro alpine types. Aside from the patches of eucalyptus trees planted by farmers and government initiated programs; there are a few dispersed indigenous tree species, shrubs and Alpine species unique to extreme highland parts of the watershed.

The watershed is occupied by a total population of approximately above 35,000 , which makes a rural crude population density of close to 146 persons $\mathrm{km}^{-2}$ which is notably higher than the regional mean of 113 persons $\mathrm{km}^{-2}$ (Estimation from Tenta district, 2016).

Agriculture is the main economic activity and source of local livelihood. Integrated subsistence level rain-fed crop cultivation and livestock rearing are the principal farming system. Farm plowing is commonly carried out with conventional ard (locally called 'Maresha') drawn by a couple of oxen. The number of tillage operation depends on plot characteristics, availability of farm tools and type of crops grown. Generally, plowing frequency ranges from 1 to 3 for every cropping season. The major cultivated crops of the area are cereals and pulses. In addition, some farmers produce oil seeds, vegetables and root crops on a small scale using traditional irrigation systems around homesteads.

Livestock rearing is an essential segment of the farming system in the watershed though ownership of livestock per household is generally declining with time due to shortage of grazing/browsing lands and subsequent animal feed constraints. Cattle, shoats and equines are the dominant livestock species in the watershed. Though

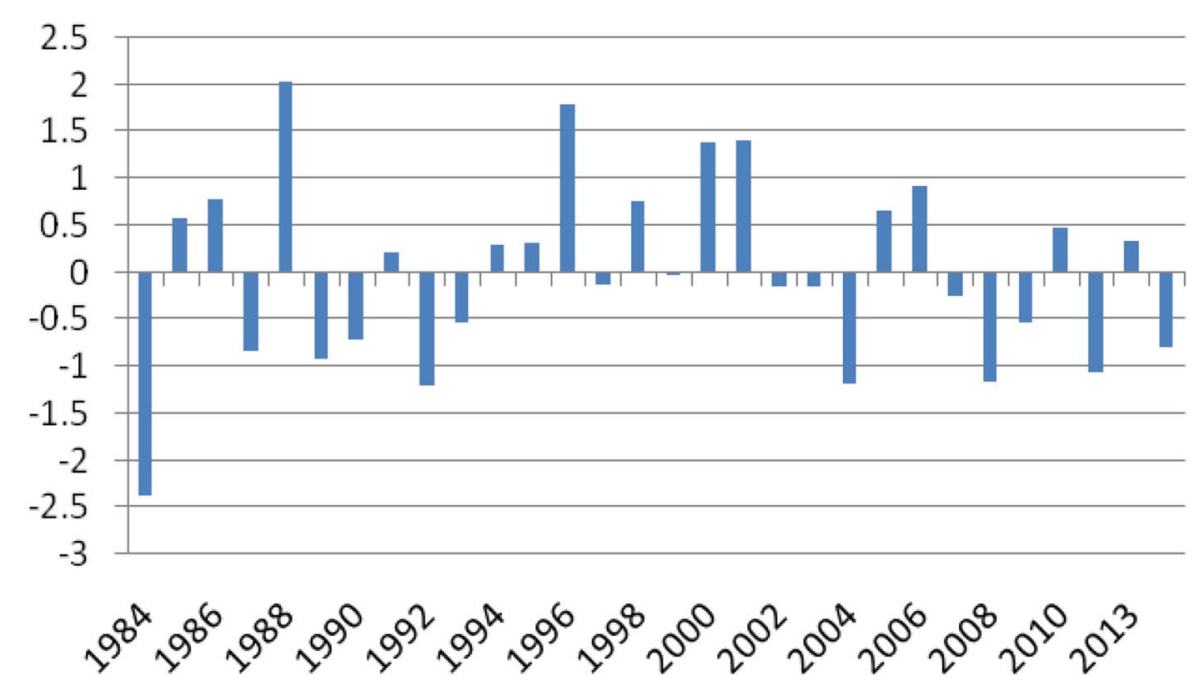

Fig. 4 Standardize Rainfall Anomaly (SRA) (1984-2014) the area (based on Ambamariam meteorological station) 


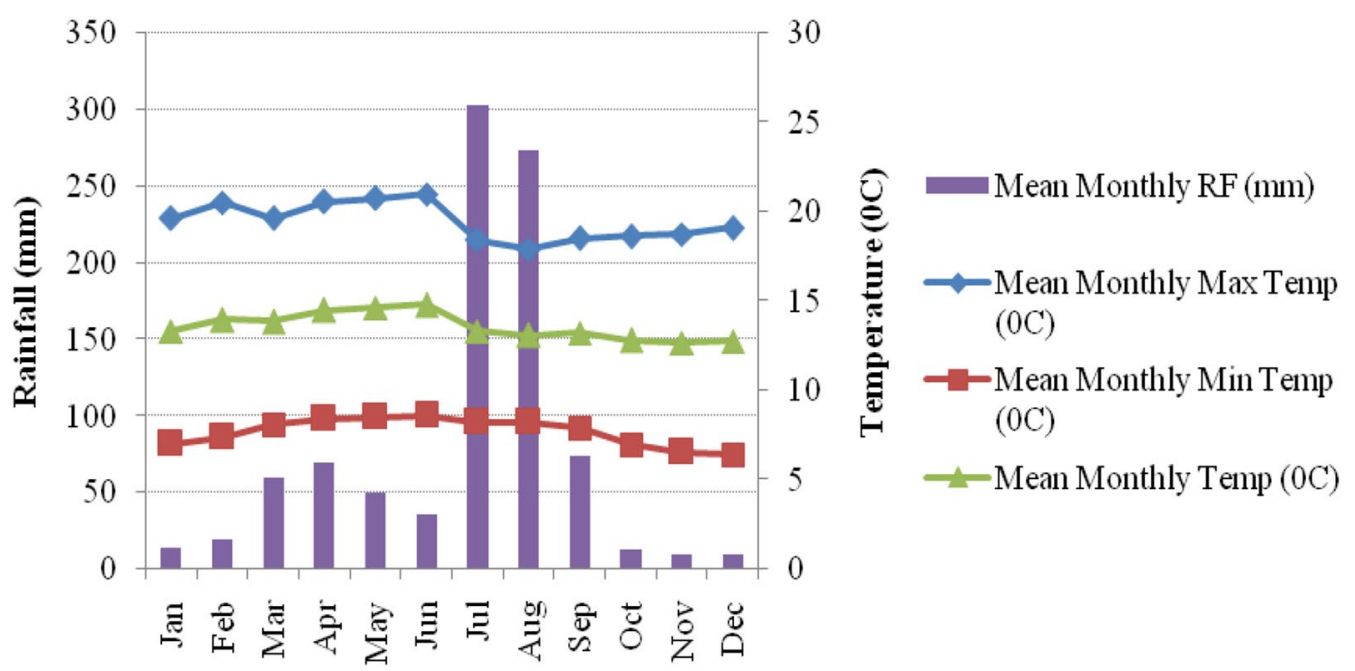

Fig. 5 Mean monthly maximum and minimum temperature and mean monthly rainfall records 1984-2017, from Ambamariam meteorological station (3000 m), South Wollo, Ethiopia

there is an effort to stop free grazing, post harvest stubble grazing is still a common practice in the area.

\section{Data type and sources}

The soil erosion process is a complicated system controlled by a multitude of factors comprising soil characteristics, local climatic conditions, nature of terrain features, ground cover, land use types, conservation practices, and interaction between them. Hence, both quantitative and qualitative methods were employed to take advantage of their complementarities and counterbalance inevitable weaknesses of each approach. With the aim of triangulation, digital and non-digital data were collected from many sources including field inspection (Table 1). Most input factor of RUSLE model was estimated using selected methodologies or obtained from literature that have been developed specifically for Ethiopian context. For each factor considered in the RUSLE model, a respective file was built in the GIS environment and finally merged together in the model to generate final map that indicates soil loss rate of the watershed. The data inputs pertaining perception and experiences of local communities were collected through one-on-one scheduled interviews with sample household's heads, focus group discussions, in-depth key informant interview, and observations of plots and its environs with sample household heads. The overall processes are depicted at Fig. 6.

\section{Soil erosion models}

Though soil erosion menace and associated land degradation and sedimentation persist throughout the geologic time scales, the circumstance is bothered in recent times
Table 1 Data type, source and description used in the study Source: Compiled by the Author, 2017

\begin{tabular}{|c|c|c|}
\hline Type of input data & Source of data & Description \\
\hline $\begin{array}{c}\text { ASTER digital elevation } \\
\text { model (ASTER DEM) }\end{array}$ & $\begin{array}{l}\text { USGS/EROS (http://gdex. } \\
\text { cr.usgs.gov/gdex/) }\end{array}$ & $30 \mathrm{~m}$ resolution \\
\hline Landsat 8 satellite image & $\begin{array}{l}\text { USGS/EROS (http://earth } \\
\text { explorer.usgs.gov/) }\end{array}$ & $30 \mathrm{~m}$ resolution \\
\hline Soil data & MoWR & $\begin{array}{l}\text { The digital } \\
\text { soil map } \\
\text { prepared by } \\
\text { the Ethiopian } \\
\text { MoWR based } \\
\text { on FAOUNE- } \\
\text { SCO-ISRIC soil } \\
\text { classification } \\
\text { system }\end{array}$ \\
\hline Rainfall data & $\begin{array}{l}\text { Ethiopian Meteorological } \\
\text { Agency }\end{array}$ & $\begin{array}{l}\text { Station and grid } \\
\text { rainfall data } \\
\text { for a period of } \\
31 \text { years }\end{array}$ \\
\hline $\begin{array}{l}\text { Land management/con- } \\
\text { servation support }\end{array}$ & $\begin{array}{l}\text { Household level survey, } \\
\text { key informant interviews } \\
\text { field observation, google } \\
\text { earth images, SAS planet } \\
\text { and literature review }\end{array}$ & $\begin{array}{l}\text { Data on the } \\
\text { state of the } \\
\text { watershed } \\
\text { such as kind } \\
\text { of support } \\
\text { practice, land } \\
\text { use/cover, } \\
\text { conservation } \\
\text { strategies etc. }\end{array}$ \\
\hline
\end{tabular}

with man's expanding mediations with the natural environment. Thus, estimation of soil erosion has become a basic issue and remains being one of the real research topics at various spatial and temporal scales using proper model (Ganasri and Ramesh 2016). 


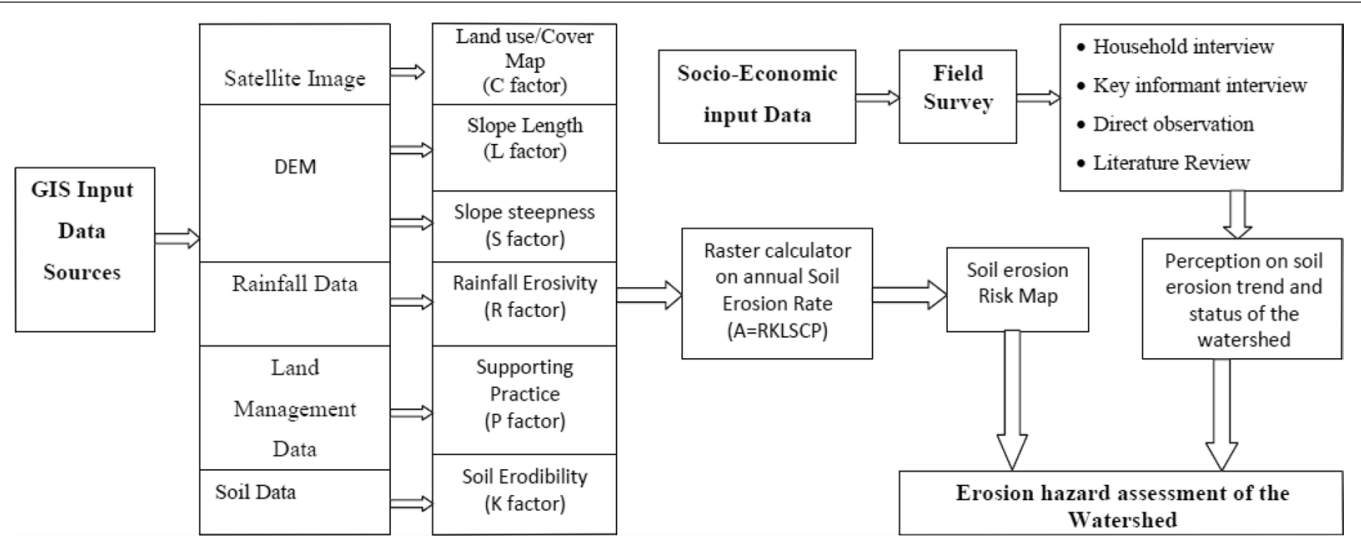

Fig. 6 The overall sequential step used employed to estimate soil loss by RUSLE model

There are a wide variety of models used to estimate soil erosion over many years worldwide (Lal 2001; Morgan 2005; Farhan and Nawaiseh 2015). These models can be physical-based, empirical, and conceptual (Brady and Weil 2012; Farhan and Nawaiseh 2015). The choice to apply these models depends on the availability of input data and type of information needed. With these in mind, The RUSLE model, which is the most widely applied empirical model, was adopted for this study. The essential supposition in the RUSLE model is that detachment and deposition are governed by the sediment load of the runoff. Soil erosion is limited by the transporting capacity of the flow instead of lack of materials eroded from the sources. If the sediment load of runoff exceeds the transporting capacity of the flow, soil detachment can no longer take place (Ganasri and Ramesh 2016).

There have been a number of studies published that apply RUSLE model to estimate and predict soil loss rate worldwide (Prasannakumar et al. 2012; Farhan et al. 2013; Ganasri and Ramesh 2016). This model, coupled with GIS and RS, has also been widely applied and tested by many researchers to estimate soil erosion potentials in the highlands of Ethiopian (e.g. Meshesha et al. 2012; Haregeweyn et al. 2013; Gelagay and Minale 2016; Fenta et al. 2016; Woldemariam et al. 2017; Haregeweyn et al. 2017). These studies supported the existing literature that indicates the efficacy of RUSLE model to adequately estimate soil loss rate in a wide range of environments.

However, the model only addresses rill and inter-rill erosion induced by the impacts of raindrops and surface runoff without accounting for other forms of erosion such as gully development and sliding of lands (Renard et al. 1997). Moreover, RUSLE model has the tendency to overestimate soil loss for a higher range of slopes and heterogeneous landscapes (Renard et al. 1991).
Nevertheless, due to complete absence of the required data (e.g. sediment deposition and shorter interval rainfall intensity data), to select other data intensive models, RUSLE model was still adopted to be applied for investigating the amount of mean annual soil loss within the study watershed. Some of the reasons for the selection the model include its less data requirements, free and readily availability of the required of data sets; its relative simplicity to apply and its compatibility with remote sensing and GIS inputs in computer interface (Farhan and Nawaiseh 2015). Moreover, most of the input parameters of the model are calibrated for the Ethiopian context (Hurni 1985). Most importantly, although many researchers employed RUSLE models to assess rate and patterns of soil loss in other parts of the Ethiopian highlands (e.g. Gelagay 2016; Tamene et al. 2017); this model was probably used for the first time to assess soil loss rate in a GIS framework in the Gedalas watershed of the Beshillo Catchment.

\section{RUSLE model structure and parameters description}

To estimate annual mean soil erosion caused by rainfall, and identify the spatial pattern of the potential soil loss risks in the watershed, RUSLE model erosion input factors were structured in raster format of five multiplicative Eq. (1) (Renard et al. 1997) and given as follows:

$$
\mathrm{A}=\mathrm{R} * \mathrm{~K} * \mathrm{LS} * \mathrm{C} * \mathrm{P}
$$

where $\mathrm{A}=$ average annual soil loss per unit of area (ton $\mathrm{ha}^{-1}$ year ${ }^{-1}$ ); $\mathrm{R}=$ the rainfall erosivity factor [MJ mm, $\left(\mathrm{ha}^{-1} \mathrm{~h}^{-1}\right.$ year $\left.\left.{ }^{-1}\right)\right]$; derived from daily precipitation data; $\mathrm{K}=$ the soil erodibility factor [ton $\mathrm{ha}^{-1}$ $\mathrm{h} \mathrm{MJ}^{-1} \mathrm{ha}^{-1} \mathrm{~mm}^{-1}$ )]; derived from information on soil types; $\mathrm{LS}=$ topographic factor, i.e., length of the slope and percent of the slope steepness (dimensionless), respectively; derived from a $\mathrm{DEM} ; \mathrm{C}=$ the land cover 
and management factor (dimensionless); derived from LULC classification of satellite image data; and $\mathrm{P}=$ the conservation support factor, which accounts for soil erosion control measures (dimensionless) derived from field observation and literature.

\section{Rainfall erosivity factor (R)}

Rainfall erosivity $(\mathrm{R})$ is the power of rain to induce soil erosion. In this study, it represents the power of an average annual value of precipitation to cause soil erosion (Lal 1990; Farhan and Nawaiseh 2015, Tamene et al. 2017). The $\mathrm{R}$ factor is a complex process potentially affected by the amount, duration, intensity, energy and size of rain drops and pattern of rainfall and rate of the resulting runoff (Farhan and Nawaiseh 2015). This factor is considered as the most influential for soil erosion in different studies (Wischmeier and Smith 1978). Rainfall erosivity can be derived from rainfall intensity for the particular period of the area considered (Kouli et al. 2009; Renard et al. 1997). However, such data are not readily available at many meteorological stations, including the study area, due to absence of automatic rain gauges. For this reason, $\mathrm{R}$ factor was estimated from the long-term mean annual precipitation values of the watershed (Renard et al. 1997).

In this study, the rainfall erosivity factor of the watershed was generated based on both observed average annual precipitation $(\mathrm{mm})$ data (Converted from daily average) recorded by Amba Mariam rainfall station and gridded rainfall data. As noted by Panagos et al. (2015), since annual rainfall erosivity significantly fluctuates, at least 15 years of data are mandatory to attain representative estimates of rainfall erosivity. Moreover, the altitude of the watershed extends from 1919 to $4233 \mathrm{~m}$ a.s.l. This may cause variations in spatial and temporal distributions of the prevailing rainfall in the watershed. With this in mind, and to adequately represent rainfall characteristics of the entire watershed, more than 30 years of 10 sites (from within and around the watershed) reconstructed gridded rainfall data series were used in conjunction with rainfall data from Amba Mariam meteorological station. Similar approaches were employed by Asfaw et al. (2018). The reconstructed gridded data with spatial resolution of $10 \times 10 \mathrm{~km}$ and temporal resolution of 10 days were obtained from NMA of Ethiopian. Since gauge weather stations are limited in number and distribution, the reconstructed gridded data were used for this study. As noted by Mengistu et al. (2013), there is a strong association $(r=0.8)$ between the station based observed and reconstructed gridded data. Hence, filling the gap with reconstructed data for this study where there is a paucity of meteorological stations is reasonably appropriate.

The daily rainfall data from the identified grid sites and the Amba Mariam station was first summed to get annual rainfall amounts and annual mean rainfall was generated for each station for the years considered. Then, the $\mathrm{R}$ factor value was calculated following the readily available regression equation developed by Hurni (1985) to estimate rainfall erosivity for the Ethiopian highlands (Eq. 2)

$$
\mathrm{R}=-8.12+(0.562 * \mathrm{P})
$$

where, $\mathrm{R}$ refers to the rainfall erosivity factor while $\mathrm{P}$ denotes to the mean annual Precipitation $(\mathrm{mm})$.

Finally, the annual rainfall amounts were spatially interpolated using an inverse distance weighting (IDW) interpolation techniques and erosivity raster map was prepared for the whole watershed with the aid of ArcGIS 10.3 software. IDW interpolation techniques has been preferred as geo-statistical spatial interpolation methods because it is easy to generate relatively accurate rainfall erosivity information from known sample points to the points of unknown values at a closer distance than those located far. Moreover, it is favored with the assumption that it enables quick interpolation of the required data from grid based irregularly spaced samples ( $\mathrm{Li}$ and Heap 2008). The $\mathrm{R}$ value ranged from 513 to $519 \mathrm{MJ} \mathrm{mm} \mathrm{ha}^{-1} \mathrm{~h}^{-1}$ year $^{-1}$. A similar approach was adopted to compute the $\mathrm{R}$ factor in Ethiopia (Bewket and Teferi 2009; Abate 2011). Figure 7 shows the rainfall erosivity values and spatial distributions across the watershed.

\section{Soil erodibility factor (K)}

Soil erodibility is the inherent aspect of soil properties reflecting the vulnerability of a soil to erode, as influenced by the biophysical and chemical characteristics of the soil (Renard et al. 1997; Farhan and Nawaiseh 2015; Panagos et al. 2015; Fenta et al. 2016). There are different approaches developed by scholars to determine soil erodibility factors (Romkens et al. 1997). However, the type of data available in the study area governs the choice of the approaches. Due to paucity of data, only soil colors and stone covers were selected to determine $\mathrm{K}$ factor values for this study as recommended by Hurni (1985) for Ethiopian conditions. The soil units map of the watershed was extract from the digital soil map of the master plan of Blue Nile basin which was prepared by the then MoWR of Ethiopia (MoWR 1998). Then, four dominant soil units; namely, Leptosols, Regosols, Cambisols and Vertisols were identified (Fig. 8) and delineated on the map of the watershed using ArcGIS 10.3 "Spatial Analyst" Geo processing tool. To validate the value of the K-factor, actual observation and field based soil sample color estimation was carried out using a Munsell color chart.

Since stone covers reduce soil erodibility by a certain percent (Panagos et al. 2015), the role of stone cover on 


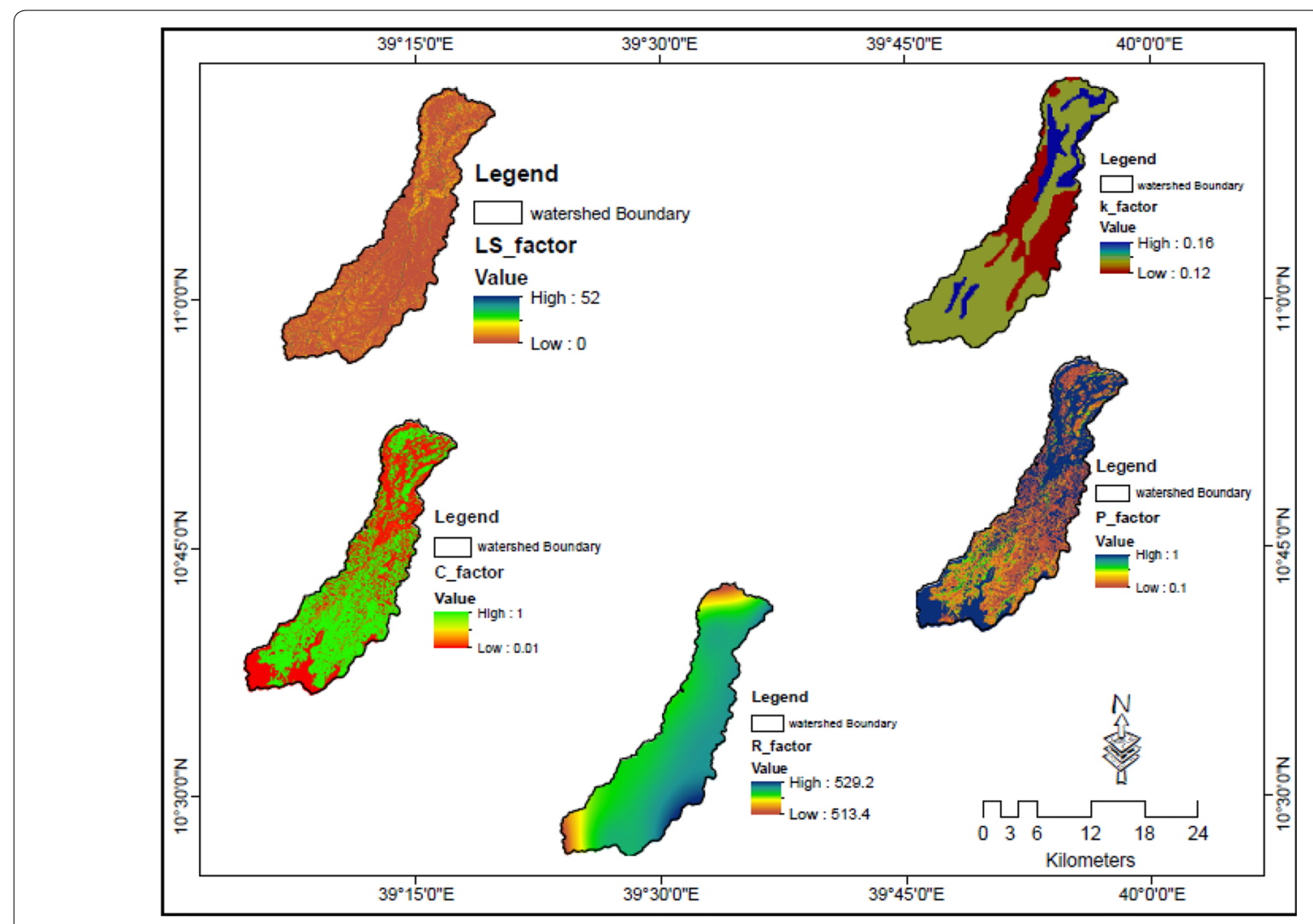

Fig. 7 spatial distributions of LS, K, C, P and R factor on the Gedalas watershed, 2018

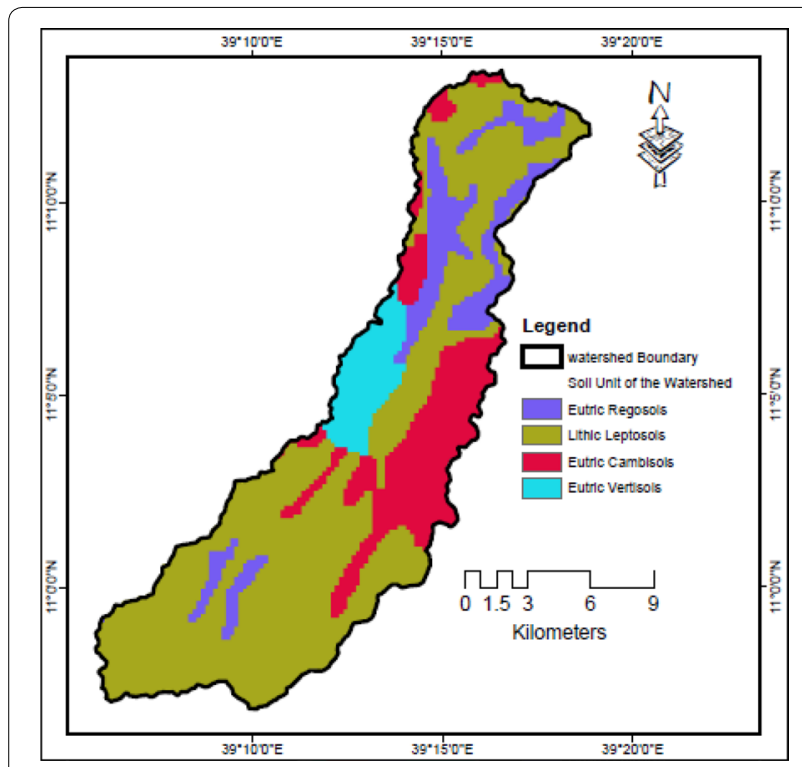

Fig. 8 Dominant soils types of the watershed

the $\mathrm{K}$-factor was incorporated in the $\mathrm{K}$ factor estimation. As observed from field survey and the author's knowledge of the area, most surfaces of soil units of the watershed are interspersed with stone contents which are protection against soil erosion by water (Poesen et al. 1994). Accordingly, 40\%, abundant of surface rock fragments and corresponding 0.80 erodibility values was assumed for all soil units (Fenta et al. 2016). Estimation of surface rock fragments of each soil unit was conducted during a transect walk based on FAO guidelines for soil description (FAO 2006). Finally, $\mathrm{K}$ factor values of the dominant color were assigned to each soil units and the soil erodibility (K) map of the watershed having a grid size of $30 \mathrm{~m}$ was produced.

The $\mathrm{K}$ value varies from 0 to 1 , where the former suggest less and the later imply high susceptibility to erosion risk, respectively (Farhan and Nawaiseh 2015). The soil erodibility map is shown in Fig. 7.

\section{Topographic factor (LS)}

Local topographic factor is the most susceptible parameter of RUSLE in the soil loss estimation (Renard et al. 1997). The LS factor describes the combined effects of slope length $(L)$ and slope gradient $(S)$, which strongly controls the transport of soil particles. LS represent the proportion of soil loss per unit area on a site to the corresponding loss from a $22.13 \mathrm{~m}$ long plot with a $9 \%$ 


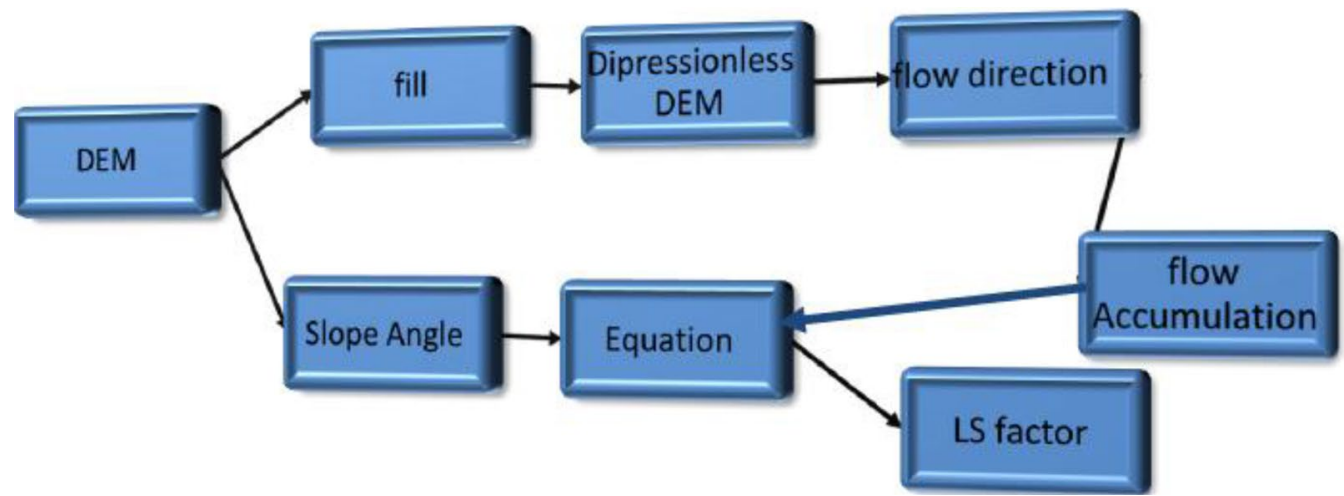

Fig. 9 Steps followed in generating LS factors in ArcGIS software

slope gradient under otherwise identical conditions. The $L S$ factor increased with slope length and slope gradient. S-factor signifies the gradient that controls the flow velocity. The steeper the slope of the land the higher will be the speed and erosive power of runoff (Wischmeier and Smith 1978; Renard et al. 1997).

Wischmeier and Smith (1978) and Renard et al. (1997) defined slope length as "the horizontal distance from the origin of overland flow to the point where either the slope gradient decreases to a point at which deposition begins or runoff becomes concentrated in a defined channel".

The amount of cumulative runoff increases with slope length. This is because the volume of runoff becomes more and more as it proceeds to the lower slope due to flow received from positions immediately upslope of the point and the flow generated within the point itself (Renard et al. 1997). L-factor was computed by dividing the contribution area by the width over which flow can pass within a grid cell (Oliveira et al. 2013).

Since manual Field measurement and determination of slope in a complex topography is difficult, if not impossible, DEMs were used to drive $\mathrm{L}$ and $\mathrm{S}$ parameters as suggested by Moore and Burch (1986), Dikau (1989), Mitasova and Mitas (1999), and Simms et al. (2003). Despite lots of methods are available for estimation of LS factor in the literature, the equations proposed by Moore and Wilson (1992) were adopted for this study to extract LS factor values from a $30 \mathrm{~m}$ resolution SRTM DEM data using map algebra expression of Arc GIS raster calculator as shown in Eq. (3). This equation was selected as it has been widely used and tested in several studies in Ethiopia context (e.g. Fenta et al. 2016).

$$
\mathrm{LS}=\left(\frac{\beta \chi}{22.13}\right)^{0.5} \times\left(\frac{\sin (\theta)}{0.0896}\right)^{1.3}
$$

where, $\beta$ is flow accumulation, $x$ is grid cell size $(30 \mathrm{~m}$ was employed in this study), 22.13 is the RUSLE standard plot length; 0.5 is the exponent of slope length; $\theta$ is slope in degrees (i.e. Slope of DEM $\times 0.01745$ ).

A step wise procedure was followed to generate LS factor map using the hydrology extension spatial analyst tool of the Arc GIS. Since the topography of the study watershed is generally dominated by steep slope areas, a limit was set for maximum slope in order to avoid excessively high slopes perforating into the model. Steps followed in generating LS factors and LS map is shown in Figs. 7 and 9 , respectively.

\section{Land cover and management factor ( $C$ factors)}

The C-factor illustrates how different LULC types (such as cropland, forest, grassland, etc.) affect soil loss rates (Renard et al. 1997). Estimation of the $C$ factor values in the RUSLE model requires data related to soil management status, the role of plant canopy and crop residues as a soil cover, soil surface roughness, and soil moisture status. However, the evaluation of each of this parameter is difficult due to many possible combinations and scarcity of data (Renard et al. 1997; Farhan and Nawaiseh 2015).

To assign $C$ factor value of this study, the Land satbased LULC classes created in 2017 for the watershed was employed (Fig. 10 and Table 2). For this end, the watershed was categorized into the required LULC classes and the $\mathrm{C}$-factor values were determined from these LULC maps of the watershed. Then, the raster map was converted to vector format to assign the corresponding $\mathrm{C}$ factor value of each land use/cover class based on available literature recommendations in the Highlands of Ethiopian (Tables 1, 3, 4). C factor map is depicted in Fig. 7. 


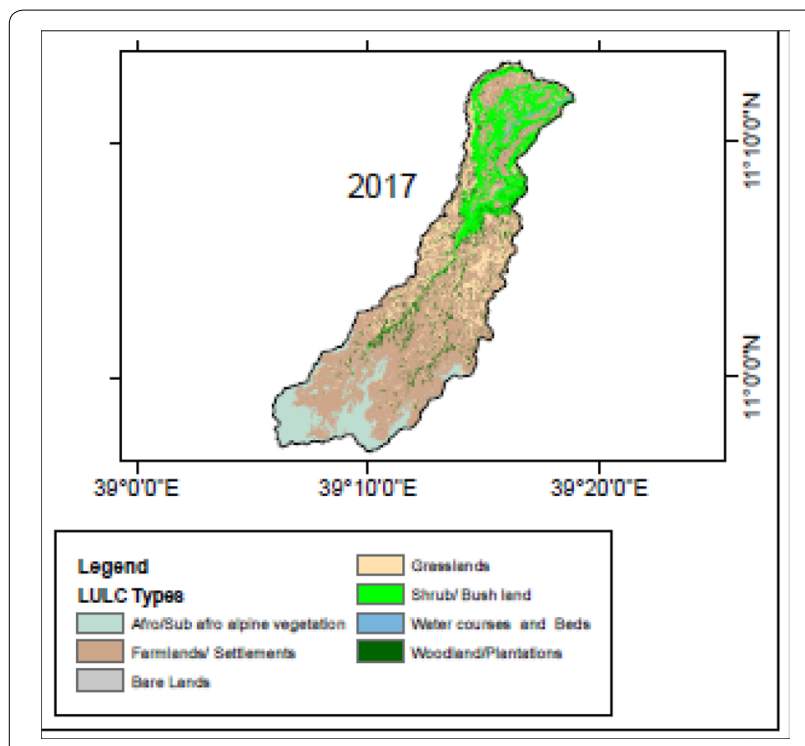

Fig. 10 Land use and land cover map of Gedalas watershed

Table 2 Area cover of the land use/cover classes of the watershed at different periods of time

\begin{tabular}{lcc}
\hline Land use/cover type & $\mathbf{2 0 1 7}$ & \\
\cline { 2 - 3 } & Area (ha) & \% of total \\
\hline Afro/sub afro alpine vegetation & 513 & 4.66 \\
Bare lands & 613 & 2.56 \\
Farmlands/settlements & 12,815 & 53.46 \\
Grasslands & 3040 & 12.68 \\
Shrub/bush lands & 3010 & 12.56 \\
Water courses/beds & 91 & 0.38 \\
Woodlands/plantations & 888 & 0.70 \\
Total & 23,970 & 100.00 \\
\hline
\end{tabular}

\section{Support practice $(P)$ factor}

Support practice (P) factor refers to "the ratio of soil loss with a specific support practice to the corresponding loss with up and down slope tillage" (Wischmeier and Smith 1978; Renard et al. 1997). The P-factor refers to different land use management practices that trim down the erosion potential of runoff concentration, runoff velocity and forces that exerted on the surface of soil (Renard et al. 1997; Panagos et al. 2015). Of all the erosion factors, values for $P$ are the least reliable (Renard et al. 1991). This is due to the difficulty in identifying its characteristics in the field.

Google earth, SAS planet software (used to look at high resolution satellite image) and field observations were used in order to investigate the support practice factor (P) available in the watershed. Soil/stone bunds (level/ graded), stone faced soil bunds, hillside terraces stabilized and reinforced with tree planting, trenches, diversion ditches, cut-off drains and waterways, stone check dams and gully rehabilitation, establishment of area closure and to a limited extent afforestation and revegetation of degraded and fragile hillside areas have been implement in the watershed. Though it was not widespread, indigenous soil conservation measures such as grass strips (locally known as Weber) and drainage ditches (to safely guides runoff off-farmlands) have been practiced by some farmers in the watershed.

However, it was witnessed that though sustainable land management program target sites have properly installed SWC structures, the largest segment of the watershed have either poorly designed or totally destroyed support measures. Moreover, as it was observed from the field visits in the watershed, most of conservation structures were widely spaced against technical recommendation and there was no proper maintenance carried out on the previously established structures. Even degraded hillsides which were once restored through project support, currently exposed to degradation due to poor management activities and limited active involvement of farmers and their related institutions in the management process. Therefore, it is not logical to use these support factors as an input data in evaluating soil loss rate in the watershed.

Hence, the watershed was categorized into agricultural land and other LULC types as suggested by Wischmeier and Smith (1978). Since land management activities are highly dependent on slope classes, agricultural lands were again categorized into six slope classes (Table 5) and for each respective slope class p-values were assigned (Wischmeier and Smith 1978). While for the other LULC classes in the watershed, a uniform default value of 1 was

Table 3 Soil units, colors and their corresponding K factor value Source: Modified from Hurni (1985), Fenta et al. (2016), Gelagay and Minale (2016)

\begin{tabular}{llc}
\hline Dominant soil types & Landform facet & Dominant soil color \\
\hline Lithic Leptosols & Sloping land, crests and ridges, and rock outcrops & Brown or yellowish (7.5YR 4/3) \\
Eutric Cambisols & Undulating plains and plateaux & Very dark gray (10YR 3/1) \\
Eutric Vertisols & Flat to almost flat topography & Very dark grayish brown (10YR 3/2) \\
Eutric Regosols & Rolling plains, side slopes and dissected plateau & Very dark brown (10YR 2/2) \\
\hline
\end{tabular}


Table 4 Adopted values of RUSLE C-factors for different land use/cover in the Ethiopian highlands Source: Compiled by the Author, 2017

\begin{tabular}{lll}
\hline Land-use/cover type & Cover factor (C) & References \\
\hline Cultivated land (cereals, pulses) & 0.15 & Hurni (1985), Bewket and Teferi (2009) \\
Afro/sub afro-alpine & 0.01 & Bewket and Teferi (2009) \\
Bush/shrub & 0.05 & Tamene et al. (2014), Haregeweyn et al. (2013) \\
Open woodland/plantation forest & 0.06 & Eweg and van Lammeren (1996) \\
Bare land/soil & 1 & Eweg et al. (1998), Hurni (1985) \\
Grassland/grazing land & 0.05 & Hurni (1985), Bewket and Teferi (2009); \\
Water courses and beds & 1 & \\
\hline
\end{tabular}

Table 5 Land management factor (P) values suggested by Wischmeier and Smith (1978) Source: Author's analysis, 2018

\begin{tabular}{llll}
\hline Land use & Slope category (\%) & P factors & References \\
\hline Cultivated land & $0-5$ & 0.10 & Wischmeier and Smith (1978), Hurni (1985), Bewket and Teferi (2009), Gelagay and Minale \\
& $5-10$ & 0.12 & $(2016)$ \\
& $10-20$ & 0.14 & \\
& $20-30$ & 0.19 & \\
& $30-50$ & 0.25 & \\
& $50-100$ & 0.33 & \\
Other land use & All & 1 &
\end{tabular}

assigned for the (P) factor regardless of the slope class they have as recommended by previous scholars who carried out comparable research in the Ethiopian highlands (Abate 2011; Bewket and Teferi 2009; Gelagay and Minale 2016; Gashaw et al. 2017).

The ArcGIS processing tool was employed to generate the thematic map. The values of $\mathrm{P}$ factor range from 0 to 1 and lower value indicates relatively better soil erosion control measures. The $\mathrm{P}$ value was assigned based on literatures and the previous empirical values adapted to Ethiopian condition (Table 6). P factor map is portrayed in Fig. 7.

\section{Approaches for validation of model results}

Due to lack of previous case studies specific to the study area, the validity of the model outputs was compared with numerical data outputs of similar studies over Ethiopian highlands. Qualitative approach such as use of perception of local communities on soil erosion status was used. To help farmers better explain the severity and onsite soil loss occurrence, the appraisal was carried out during the rainy season of the year (Diwediga et al. 2018). In addition, selective field observations were carried out to identify most erosion prone areas. In supporting these processes, the color printed model output soil erosion severity map was taken in the field to check it on the ground and compare the model result with community perception.

\section{Data analysis techniques}

To identify the contribution of each parameter in RUSLE model, each factor was calculated as a specific thematic layer on the cell by cell bases (Millward and Mersey 1999). Since both the Landsat images and the DEM used in this study had $30 \mathrm{~m}$ spatial resolution, all the required data layers were co-registered to a common pixel resolution and datum. After completing data input procedures and arranging each information layer, the mean annual soil loss was calculated by multiplying each factor layers together according to the RUSLE formula (Eq. 1) using the raster calculator of map algebra functions and associated packages in a GIS framework.

Then, the estimated annual mean soil loss rates were displayed in map showing spatial distributions of erosion risk for the watershed and details of statistical soil erosion intensity classes and ranges of soil loss rates were identified and categorized following the FAO soil description guidelines (FAO 2006) and expertise judgment, with some modification to suit the local condition of the watershed as depicted in Table 6. Finally, the spatial differences in rate of soil erosion in relation to corresponding LULC categories, slope classes and agro ecologies were evaluated by using the zonal statistics 
Table 6 Annual soil erosion rates, magnitude and area coverage

\begin{tabular}{|c|c|c|c|c|c|c|}
\hline $\begin{array}{l}\text { Soil loss rates }(\mathrm{t} \\
\left.\mathrm{ha}^{-1} \text { year }^{-1}\right)^{\mathrm{a}}\end{array}$ & Severity classes ${ }^{a}$ & Area (ha) & Percent of total & $\begin{array}{l}\text { Estimated annual } \\
\text { loss (ton) }\end{array}$ & Percent of total & $\begin{array}{l}\text { Priority class } \\
\text { for conservation }\end{array}$ \\
\hline$<5$ & Very slight & 10,290 & 42.9 & $88,318.08$ & 7.1 & 5 th \\
\hline 5 to 15 & Slight & 7424 & 31 & $364,781.6$ & 29.3 & 4 th \\
\hline 15 to 30 & Moderate & 2707 & 11.3 & $317,712.3$ & 25.5 & $3 \mathrm{rd}$ \\
\hline 30 to 50 & Severe & 1701 & 7.1 & $325,624.3$ & 26.2 & 2nd \\
\hline$>50$ & Very sever & 1848 & 7.7 & $147,137.2$ & 11.8 & $1 \mathrm{st}$ \\
\hline Total & & 23,970 & 100 & $1,243,574$ & 100 & \\
\hline
\end{tabular}

a This classification was made based on soil erosion literature on the Blue Nile Basin (e.g. Haregeweyn et al. 2017)

function of the spatial analyst tools in ArcGIS software and the results were supplemented by local community perceptions (Fig. 6).

\section{Results and discussion}

\section{Estimation of annual soil loss in Gedalas watershed}

The computed annual values of soil loss of the watershed ranged from 0 in plain areas to well over 150 $\mathrm{t} \mathrm{ha}^{-1}$ year $^{-1}$. In the lower reach degraded sloping areas, banks of streams and at the specific spots of steep slopes of the watershed soil loss rate exceed $935 \mathrm{t} \mathrm{ha}^{-1}$ year $^{-1}$ (for a visual comparison of results, see Fig. 11). The annual mean soil loss value for the watershed was around $37 \mathrm{t} \mathrm{ha}^{-1}$ year $^{-1}$, whereas $51 \mathrm{tha}^{-1}$ year $^{-1}$ was found on the croplands, which comprises the largest quantity of annual mean soil loss in the watershed.

These are comparable to the loss of around $4 \mathrm{~mm}^{1}$ of depth of topsoil per year (Hurni 1983). The overall average soil loss rates of the watershed are higher as compared to soil formation rate for the various land units of Ethiopia, which ranges from 2 to $22 \mathrm{t} \mathrm{h}^{-1}$ year ${ }^{-1}$ (Hurni 1983). If we compared the estimated soil loss result to the limits of soil loss tolerance ${ }^{2}$ suggested by Rose (1994) (10 $\mathrm{t} \mathrm{ha}^{-1}$ year $^{-1}$ for tropical region) and Hurni (1986) 2-18 tha $\mathrm{ha}^{-1}$ year $^{-1}$ for the various agro-ecological belts of Ethiopia and $10 \mathrm{t} \mathrm{ha}^{-1}$ year $^{-1}$ to the northern highlands of Ethiopia, it is still higher despite conservation efforts through an integrated watershed management approach in place. Moreover, as per the recommendation of Morgan (1995), annual soil loss threshold for the sustainable agricultural lands use is 10 ton ha ${ }^{-1}$. According to Kouli et al. (2009), any soil loss rate which exceeds $10 \mathrm{t} \mathrm{ha}^{-1}$ year $^{-1}$ will not be reversed in a time span of 50 to 100 years. Considering this threshold, the total area with a soil erosion risk higher than the soil loss tolerance was 6256 ha (Table 6 and Fig. 11), comprising 26.1\% of the entire watershed area (Table 6)
However, it should be noted that the judgment of what level is tolerable depends on the local situation and in particular the type and depth of soil, the rate of soil formation, land use/cover status, topography and amount, intensity and duration of rainfall (Foster et al. 2002).

The estimated soil loss values and its spatial distribution in the watershed is generally reasonable, compared to what can be seen in the field and weighed against similar studies reported by FAO (1986) in the central and northern highlands $\left(35 \mathrm{t} \mathrm{ha}^{-1} \mathrm{year}^{-1}\right)$ and SCRP (1996) in the South Wollo Zone $\left(35 \mathrm{tha}^{-1}\right.$ year $\left.^{-1}\right)$.

Contrary to this finding, other similar studies undertaken in different parts of the highlands of the country reported a relatively higher average soil loss rates. For instance, the computed result of this study was lower than the mean soil loss rate of $243 \mathrm{t} \mathrm{ha}^{-1}$ year $^{-1}$ by Gete (2000) in northwestern highlands of Ethiopia; 93 $\mathrm{t} \mathrm{ha}^{-1}$ year $^{-1}$ by Bewket and Teferi (2009) in the Chemoga watershed; $84 \mathrm{t} \mathrm{ha}^{-1}$ year $^{-1}$ by Yihenew and Yihenew (2013) in Northwestern Ethiopia; $47.4 \mathrm{t} \mathrm{ha}^{-1}$ year $^{-1}$ by Gelagay and Minale (2016) in the Koga watershed; 45 $\mathrm{t} \mathrm{ha}^{-1}$ year $^{-1}$ by Wolka et al. (2015) in parts of Ethiopian rift valley, and from 0.2 to $321 \mathrm{t} \mathrm{ha}^{-1}$ year $^{-1}$ by Amare (2007) in the eastern escarpment of Wollo. Plot level experiments conducted in different SCRP stations at various spatial and temporal scales also showed differences in soil loss rates (e.g. at Andit tid 87-212 t ha ${ }^{-1}$ year $^{-1}$ (1983-1992); at Anjeni 131-170 t ha ${ }^{-1}$ year $^{-1}$ (1985 to 1993).

The above report highlights that though soil erosion endangers the soils in the Ethiopian highlands, the quantitative soil loss estimation is still uncertain and inconsistent. Nonetheless, it is imperative to note that all the above quantitative information pointed to general soil erosion problems in the highlands of Ethiopia in general and the study watershed in particular.

\footnotetext{
${ }^{1}$ Hurni (1983) stated that " 1 ton annual soil loss per ha is equivalent to loss of $0.12 \mathrm{~mm}$ soil depth in the area".

${ }^{2}$ As defined by Renard et al. (1997), "the extent to which soil loss can be tolerated".
} 


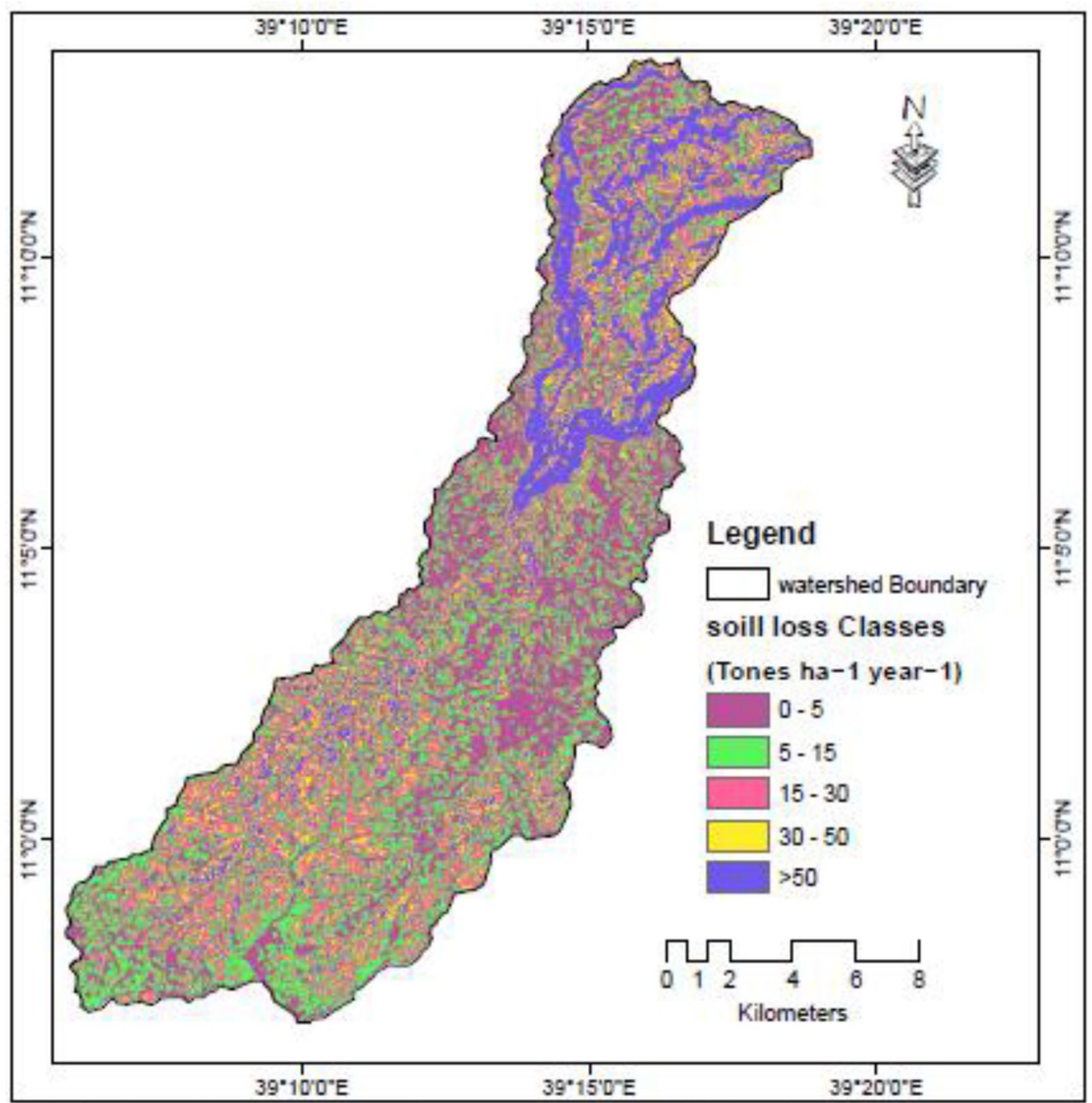

Fig. 11 Map depicting spatial variation of soil erosion loss in Gedalas watershed

The possible causes of disparities in estimates could be differences in time and assessment scales, variations in input data, lack of correspondence in the methods adopted combined with the high heterogeneity of the environment in which the studies carried out. In this respect, Haregeweyn et al. (2015) reviewed that variation in mean annual rainfall and its associated erosive power was found to explain more than one-third (35\%) of the soil loss variations.

\section{Spatial variation of annual soil loss in Gedalas watershed} As demonstrated in Table 6, the spatial patterns of annual average soil loss distribution were grouped into five erosion intensity classes. The study revealed that $42.9 \%$ of the watershed experiences very slight rates of soil erosion, whereas areas affected by slight and moderate rates of soil loss encompass $31 \%$ and $11.3 \%$ respectively. In total, areas affected by severe and very sever soil loss rates covers approximately $14.8 \%$ of the watershed (Table 6). This implies that most of the total soil loss was generated from the small areas which experiences high erosion rates (Fig. 11)

From the from the spatial patterns of soil erosion hazard map (Fig. 11), it is evident that nearly the whole watershed areas require implementation of one sort or more of SWC measures to ensure sustainability of land use. However, in the southwestern areas of the watershed, the extent of soil loss is relatively lower than the northeastern parts. This could be due to the fact that the southwestern part of the watershed was pilot sites of Sustainable Land Management (SLM) Projects and hence there are different conservation interventions such as 
area closure, terrace, grass strip management and controlled grazing, among others. Moreover, this part of the watershed is situated in mountainous regions of Afro/ sub Afro alpine areas. Thus, it is relatively far away from direct and significant impact of accelerated soil erosion. Nevertheless, it ought to be noted that since this part of the watershed is characterized by highly elevated, steep slope and rugged topographic areas, the actual soil loss rates may be underestimated as RUSLE model cannot predict soil loss from caused by gravity flow.

Most of the current soil erosion risk areas are spatially confined in the steep slope Northeastern parts of the watershed. It is believed that this part of the watershed is primarily characterized by shallow soils, Steep slopes, and sparse vegetation covers. Moreover, unsustainable land management practices on sloping lands have accelerated the magnitude of soil erosion. During the field visit, this part of the watershed comparatively exhibited low level of SWC structures and removal of the vegetation cover.

Therefore, it should be realized that these parts of the watershed needs urgent and prioritized intervention with appropriate SWC measures by the local governments. In fact, as observed from the field survey and information obtained from local informants, there were long aged attempts to delineate and put aside steep slope areas in this part of the watershed as enclosures. However, sustaining the positive achievements in controlling soil erosion is still a major challenge in the area.

\section{Soil erosion along slope classes of the watershed}

As noted above, slope angle and slope length are the two main factors which significantly influence soil erosion rates in the study area. As expected, areas with steep slope topography have much more soil erosion rates than areas with gentle slopes. The results clearly demonstrate that almost $2 / 3 \mathrm{rd}$ of the watershed area (70.6\%) situated on the sloping terrain. When viewed from slopes perspective, the spatial distribution of soil loss rates increases linearly with increasing slope gradient across the watershed (Table 7). The watershed areas with slope gradients higher than $60 \%$ experiences soil loss rates ranging from 91 to 935 ton $\mathrm{ha}^{-1}$ year $^{-1}$. This implies that slope plays significant role in accelerating soil erosion rates in the area and hence a reduction in slope length through various SWC structures should be a concern of priority. In agreement with the model estimated outputs, local community perceptions and evaluation also indicate the occurrence soil erosion primarily on steep slopes areas all over the watershed suggesting the need for comprehensive SWC measures in accordance to slope classes.
Table 7 Annual values of soil loss for various slope classes of the watershed

\begin{tabular}{lrrrrr}
\hline Slope classes (\%) & \multicolumn{1}{l}{ Area } & & \multicolumn{2}{l}{ Estimated annual loss } \\
\cline { 2 - 3 } \cline { 5 - 6 } & ha & $\%$ & & ton year $^{-1}$ & $\begin{array}{l}\text { Contribution } \\
\text { to total soil loss } \\
\text { (\%) }\end{array}$ \\
\hline $0-5$ & 1094 & 4.6 & 5436 & 0.4 \\
$5-10$ & 1426 & 5.9 & 28,447 & 2.3 \\
$10-15$ & 2790 & 11.6 & 62,578 & 5.0 \\
$15-30$ & 3161 & 13.2 & 314,371 & 25.3 \\
$30-60$ & 6667 & 27.8 & 411,632 & 33.1 \\
$>60$ & 8832 & 36.8 & 421,110 & 33.9 \\
Total & 23,970 & 100.0 & $1,243,574$ & 100.0 \\
\hline
\end{tabular}

\section{Soil erosion across agro ecology in Gedalas watershed}

As depicted in Table 8, the spatial distribution of soil loss values varied across agro-ecologies of the watershed, regardless of land use/cover types and slope classes, with greater loss per unit area occurring from Weyna Dega compared with Wurch and Dega Areas. Although the observed contribution to total proportion of land area is higher in Wurch zone (48.7\%) and Dega zone (44.6\%) as compared with Weyna Dega (6.7\%), the highest soil loss per unit area (total soil loss to plot area ratio) is occurring in the steep slopes part of the watershed suggesting the need for targeted SWC measures and treatment of degraded landscapes. The possible explanation for the incidence of high rate of soil loss in the Weyna Dega area is the prevalence of steeper slopes along with farming on marginal lands which is not conducive for agriculture (Table 9).

It is apparent that the Wurch zone of the watershed shows the relatively low erosion rate relative to its total areas. This could be most likely attributed to presence of SLM pilot project working on the rehabilitation of degraded lands. A relatively lower soil loss in this zone also implies that project supported SWC activity play a vital role in controlling soil erosion in the watershed.

\section{Table 8 Variations of soil erosion by agro ecology}

\begin{tabular}{|c|c|c|c|c|}
\hline \multirow[t]{3}{*}{ Agro ecology } & \multicolumn{2}{|l|}{ Area } & \multirow{2}{*}{\multicolumn{2}{|c|}{$\begin{array}{l}\text { Estimated annual } \\
\text { loss } \\
\text { Contribution }\end{array}$}} \\
\hline & \multirow[t]{2}{*}{ (ha) } & \multirow[t]{2}{*}{$\%$} & & \\
\hline & & & t/year (\%) & \\
\hline Weyna Dega (<2300 m) & 1614 & 6.7 & 194,957 & 15.7 \\
\hline Dega (2300-3200 m) & 10,682 & 44.6 & 707,941 & 56.9 \\
\hline Wurch (> 3200 m) & 11,674 & 48.7 & 340,676 & 27.4 \\
\hline Total & 23,970 & 100 & $1,243,574$ & 100 \\
\hline
\end{tabular}


Table 9 Soil erosion by LULC types

\begin{tabular}{lcccc}
\hline LULC classes (2017) & Area (ha) & \% of total & Estimated annual loss \\
\cline { 3 - 5 } & & & t/year & $\begin{array}{c}\text { Contribution } \\
\text { (\%) }\end{array}$ \\
\hline Afro/sub afro alpine vegetation & & & 85,605 & 6.9 \\
Bare lands & 3513 & 2.56 & 20,122 & 1.6 \\
Farmlands/settlements & 613 & 53.46 & 529,433 & 42.6 \\
Grazing lands & 12,815 & 12.68 & 434,918 & 35.0 \\
Shrub/bush lands & 3040 & 12.56 & 59,036 & 4.7 \\
Water courses/beds & 3010 & 0.38 & 50,114 & 4.0 \\
Woodlands/plantations & 91 & 3.7 & 64,346 & 5.2 \\
Total & 888 & 100 & $1,243,574$ & 100 \\
\hline
\end{tabular}

\section{Soil erosion across LULC categories}

This study reveals considerable effects of LULC class on the extent of soil erosion in the watershed. According to RUSLE model, results estimated soil losses by water erosion were highest for croplands followed by grazing lands of the watershed. Higher soil loss in cropland is likely caused by cultivation on steep slopes, intensive plowing and mono cropping practices while high soil losses in grazing lands are associated with intensive grazing which results in removal of vegetation cover and soil compaction caused by trampling of livestock. This result, however, contradicts with the plot level finding of Nyssen et al. (2009) who documented higher soil erosion values for grazing lands as compared to that of croplands in Tigray.

The differences may be due to variations in the prevailing environmental conditions (slopes, vegetation composition, climate, soil characteristics, and land management practices) and adoption of different modeling approaches by the researchers while calculating $\mathrm{C}$-factor values in their specific study areas. It is evident from the result that the pattern of onsite soil erosion is associated with poor land management activities and suggests the need for promoting SLM practices in the watershed.

\section{Farmers' perception of soil erosion damage in the watershed}

There is an overall consensus that the model based estimation of soil erosion output could be ascertained by integrating local knowledge and perceptions of soil erosion problems. It has been also realized that understanding local perceptions and knowledge of soil erosion are vital entry points to make informed decisions on SLM practices (Amsalu and de Graaff 2006; Weldemariam et al. 2013). In this line, Heberlein (1972) stated that at the point when local communities comprehend that their physical environment is deteriorating and felt personally responsible for these outcomes, they will endeavor to control land degradation inducing actions and will show more interest to support land management programs.

With this in mind, farmer's perceptions of soil erosion incidence, levels, indicators and impacts were assessed across the three agro ecologies of the watershed. As shown in Table 10, over $98 \%$ of the farmers participating in the survey were aware of soil erosion problems-95\% in Wurch, $100 \%$ in Dega, and 100\% in Weyna Dega. Further discussions with the local community revealed that the incidence of soil erosion damage was critical during the onset of rainy season and at times of seedbed preparation where the soil is bare and loose. Moreover, during field observation, rill erosions and rock exposures were intensively visible on the arable plots and its environs suggesting the severity of soil erosion in the watershed though different attempts were/are in place to address problem. The result is comparable with the findings of other similar studies conducted elsewhere in the highlands of Ethiopia (e.g. Amsalu and de Graaff 2006).

Concerning the level of the soil erosion problem, over half of those respondents (59\% of total) who perceived soil erosion as a problem rated it as severe, $26 \%$ rated it as moderate while the remaining $10 \%$ and $5 \%$ rated it as minor and difficult to estimate respectively. Though farmers were not capable of quantitatively estimate level of soil loss per unit area, it is clear from the data that all of them acknowledged the existence and level of soil erosion in their localities. However, there is a minor difference as observed across agro ecologies. The majority of farmers residing in Weyna Dega and Dega areas recognized the problems as more severe compared to Wurch areas. As reflected from local residents, the status of soil erosion in the Wurch agro ecology (upstream areas) seems relatively low. As already noted, this is most likely attributed to the SLM interventions since the late 2014 in the area (TWARDO 2017). This result is comparable to 
Table 10 Farmers' views of soil erosion prevalence, extent, trend and indicators (\% of respondents) Sources: The author, 2017

\begin{tabular}{|c|c|c|c|c|}
\hline Farmers' perceived responses to & $\begin{array}{l}\text { W/Dega } \\
(N=76)\end{array}$ & $\begin{array}{l}\text { Dega } \\
(N=194)\end{array}$ & $\begin{array}{l}\text { Wurch } \\
(\mathrm{N}=114)\end{array}$ & $\begin{array}{l}\text { Overall } \\
(\mathrm{N}=384)\end{array}$ \\
\hline \multicolumn{5}{|l|}{ 1. Erosion faced in the locality (\%) } \\
\hline A. Yes & 100 & 100 & 95 & 98 \\
\hline B. No & 0 & 0 & 5 & 2 \\
\hline \multicolumn{5}{|l|}{ 2. Soil erosion level (\%) } \\
\hline A. Severe & 68 & 59 & 51 & 59 \\
\hline B. Moderate & 20 & 27 & 31 & 26 \\
\hline C. Minor & 9 & 8 & 13 & 10 \\
\hline D. Difficult to estimate & 3 & 6 & 5 & 5 \\
\hline \multicolumn{5}{|l|}{ 3. Change of soil erosion over time (\%) } \\
\hline A. Increasing & 91 & 57 & 56 & 68 \\
\hline B. Decreasing & 0 & 3 & 24 & 9 \\
\hline C. No change & 9 & 40 & 20 & 23 \\
\hline \multicolumn{5}{|l|}{ 4. Indicators of soil erosion problems (\%) } \\
\hline A. Field dissection and formation of gullies & 77 & 42 & 73 & 64 \\
\hline B. Development of visible rills on farmlands after erosive rain & 54 & 89 & 62 & 68 \\
\hline C. Deposition of sediment on the lower section of the farm after rainfall & 71 & 56 & 62 & 63 \\
\hline D. Decrease in soil depth & 96 & 75 & 87 & 86 \\
\hline E. The removal of seeds and seedlings & 96 & 91 & 89 & 91 \\
\hline F. Trees/crops root exposure & 76 & 68 & 65 & 64 \\
\hline G. Increase in stones cover and rock exposure & 95 & 64 & 89 & 68 \\
\hline H. Poor crop yield and vigor & 94 & 89 & 96 & 93 \\
\hline I. Damage of conservation structures & 84 & 62 & 71 & 72 \\
\hline J. Changes in surface soil color & 43 & 27 & 57 & 70 \\
\hline
\end{tabular}

${ }^{a}$ Percentage does not add up to 100 as farmers have listed more than one indicator

computed erosion rates of the RUSLE model and to what can be seen in the plots. However, the results contradict with those of Bewket and Sterk (2003) and Tefera and Sterk (2010), who reported that "the perceived severity of soil erosion was location specific, that is, relatively higher in upstream areas and lower in downstream fields".

Farmers were asked to point out the trend of soil erosion over time in their localities. Results showed that the majority $(68 \%)$ of farmers perceived an increasing trend of soil erosion while $9 \%$ and $23 \%$ of the respondents felt a decrease and no change over time respectively (Table 10). Those who reported that the problem was increasing were mainly from the Weyna Dega agro ecology where most of the area of the watershed lies on steep slopes. Responses in no change of soil erosion (40\%) were prominent in the middle portion of the watershed. This may be ascribed to the high proportion of moderately sloping land.

Farmers were asked to list soil erosion indicators which they observed in their localities and their croplands. The most frequently mentioned key indicators in almost all agro ecologies were reduced crop yield and performance
(93\%), the removal of seeds and seedlings (91\%), decrease in soil depth (86\%), increase in on farm stoniness and gradual rock exposure to the extent that prevent plowing (79\%), frequent damage of conservation structures (72\%), changes of soil color (70\%), development of visible rills on the bare soils $(68 \%)$, field dissection and formation of gullies (64\%), exposure of trees/crops roots (64\%) and deposition of sediment on the lower section of the farm (63\%) (Table 10). These perceptions of the community were in line with soil erosion indicators in the literature (e.g. Lal 2001; Morgan 1995). However, there was slight variation from one site to another in the number of farmers appraising these indicators. For example, in some areas, notably in the Dega agro-ecology, development of visible rills on farmlands after erosive rain was acknowledged as major indicators by the majority of the respondents. In contrast, a few farmers pointed out that field dissection, the formation of gullies, sediments deposition and change in depth of surface soil as significant indicators of soil erosion (Additional file 1).

Moreover, though confined to limited areas, some key elderly informants reported the emergence of some 
Table 11 Farmers' perceived causes for soil erosion (\% of respondents) Sources: The author, 2017

\begin{tabular}{|c|c|c|c|c|}
\hline Causes of soil erosion (\%) ${ }^{a}$ & $\begin{array}{l}\text { Weyna Dega } \\
(N=76)\end{array}$ & $\begin{array}{l}\text { Dega } \\
(N=194)\end{array}$ & $\begin{array}{l}\text { Wurch } \\
(\mathrm{N}=114)\end{array}$ & $\begin{array}{l}\text { Overall } \\
(\mathrm{N}=384)\end{array}$ \\
\hline 1. Erosive rains & 79 & 89 & 77 & 82 \\
\hline 2. Soils being erodible & 17 & 13 & 19 & 16 \\
\hline 3. Topography of the area & 99 & 75 & 94 & 89 \\
\hline 4. Decline in vegetation cover & 100 & 100 & 100 & 100 \\
\hline 5. Damaged conservation structures & 89 & 77 & 73 & 80 \\
\hline 6. Cultivation on steep slopes & 30 & 23 & 34 & 29 \\
\hline 7. Runoff from roadside drainage and culverts & 5 & 35 & 23 & 21 \\
\hline 8. Over grazing and impacts of cattle tracks & 33 & 21 & 23 & 26 \\
\hline
\end{tabular}

a Percentage does not add up to 100 because of multiple responses

unusual plant species (e.g. quickly spreading weed species) that signify the indicator of existence soil erosion problem in their specific sites. These impact indicators were further confirmed by the majority of focus group participants and even by local development agents.

An attempt was made to appraise the spatial distribution of the recognized indicators over the farm lands along different agro-ecologies. Results revealed that almost all the above listed indicators were observed in the entire watershed despite ongoing watershed development program. The remarkable presences of all these soil erosion indicators imply that soil erosion is still the most serious form of land degradation in the watershed.

To gain further insight into the farmers' awareness of erosion, they were interrogated to state the major causes that initiated soil erosion in their respective localities. Although some farmers held the belief that supernatural resentment is the cause for the occurrences of soil erosion in their explanations, the majority of the respondents put emphasis on combinations of causes. For instance, topography of the area, intense rainfall, poor vegetation cover and destruction of conservation structures were the most commonly ascribed causes for the ongoing soil erosion problems in the watershed (Table 11). In this vein, a 79 years old key informant farmer from the Weyna Dega area of the watershed lamented his concerns about the problem of deforestation brought about by some farmers on the future fate of farming as follows:

Some individuals don't care about their land on which their livelihood depends. They know that vegetation reduces soil erosion and improve soil fertility, but still they destroy vegetation covers as they are only interested to expand their farm land and get more produce". Another key informants from Wurch zone attributed soil erosion problems, mainly to "heavy rainfall and to frequent damage of conservation structures due to incorrect installation.
Though their percentages are relatively small, farmers also pointed out cultivation on steep slopes, the nature of the soil itself, over grazing and its associated impact as additional causes that facilitate soil erosion in their respective localities. In addition, a few (21\%) farmers mainly from Dega and Wurch agro ecologies also mentioned that their croplands had become more vulnerable to erosion because of runoff from damaged conservation structures, roadside and culverts. In FGD, in all locations, farmers concurred that they had experienced these causes, although, most farmers emphasized steep slope as the principal causes of soil erosion (Table 12).

Furthermore, farmers were asked to list the possible effects of soil erosion and they mentioned; loss of fertile soil, declining soil fertility, loss of seeds, loss of chemical fertilizers, ever increasing fertilizer requirements. Surprisingly, farmers' perception concurs with existing scientific literature (Lal 2001). However, the majority of farmers' constantly associated soil erosion impact to decline in crop production. Most key informants and discussants bear similar sentiments about the impacts of soil erosion in the watershed. For instance, one key informant (farmer) residing in the Weyna-Dega area highlighted his perceived soil erosion impact indicators this way:

Formerly, my farmland was among good land, as it was growing everything. Recently, crop production has been declining over time due to soil erosion. Whatever seed I sow productivity is too low, sometimes the crop leaves turn yellow and they finally die. The soil fertility status is poor now; it is becoming shallow and stony. We are living by scratching such lands like a hen.

Finally, farmers were asked to recommend possible solutions and curative actions to the prevailing soil erosion problems in their localities. The majority of respondents suggested more than one possible solutions including construction and maintenance 


\begin{tabular}{lllll}
$\begin{array}{l}\text { Table 12 Rain fall } \\
\text { for interpolation }\end{array}$ & erosivity & of & sample & sites used \\
\hline Site & Easting & Northing & AVR RF & R_erosivity \\
\hline Gaya & 517039 & 1211856 & 948.1944 & 524.7652778 \\
Wortej & 528381 & 1221417 & 950.3056 & 525.9517222 \\
Washera & 528315 & 1234605 & 948.8611 & 525.1399444 \\
Yekosso & 516907 & 1222538 & 945.6111 & 523.3134444 \\
Yamed & 528117 & 1244101 & 912.75 & 504.8455 \\
Gimba & 527879 & 1211066 & 971.5278 & 537.8786111 \\
Tidgebeya & 538789 & 1233349 & 980.2778 & 542.7961111 \\
Guassa & 506007 & 1210965 & 905.2778 & 500.6461111 \\
Akesta & 517335 & 1200151 & 943.6111 & 522.1894444 \\
Ambamariam & 517335 & 1232499 & 933.00 & 516.226 \\
\hline
\end{tabular}

of terraces, planting of fast growing economic trees, enclosed degraded hillsides until it rehabilitates, and implementation of proper cropping systems and other related land management practices. They further recommended Strict follow up of government regulations and respecting local bylaws set out by the farmers themselves to deal with illegal interferences by humans and livestock to communal resources and enclosed areas.

The overall results of this empirical analysis provide clear evidence that though the depth of understanding varies due to differences in socioeconomic characteristics among individuals, the majority of farmers have unequivocal and relatively inclusive sets of knowledge about prevailing soil erosion problems, indicators, causes, consequences and even remedial actions and solutions to the problem in their localities across the agro-ecologies, implying that engaging farmers can provide accurate information in assessing land degradation-restoration dynamics at local scales. This awareness of soil erosion problems probably stems from the information they acquire through their networks, their own experiences and their exposure to the government awareness campaigns. The result concurs with the findings of previous and contemporary similar research conducted elsewhere in Ethiopia (Bewket and Sterk 2003; Karltun et al. 2013; Gebremichael et al. 2015; Meshesha and Abele 2016; Assefa and Hans-Rudolf 2016; Nigussie et al. 2016).

\section{Conclusions}

Water induced soil erosion is a serious environmental and socio-economic problem in the Gedalas watershed. Although much of the erosion in the watershed was undoubtedly initiated by human activities (cultivation on a steep slope), it is apparent the biophysical factors (topography, soil type, climate, vegetation) also greatly influence rate of soil erosion by water. This study not only quantified average annual soil loss value under current conditions in the watershed but also mapped the spatial distribution of the risk of soil erosion using RUSLE model which is verified through local perceptions and field observations. The average annual soil loss value was found to be $37 \mathrm{t} \mathrm{ha}^{-1}$ year ${ }^{-1}$, which significantly exceeded the soil loss tolerances limits for Ethiopian highlands. Although, in most cases, very slight soil loss level tends to dominate, extreme and very extreme soil erosion is not uncommon for large parts of the watershed with poor vegetation cover, ineffective conservation practices, bare lands, steep slopes and mountainous areas.

The watershed map of soil erosion risk generated in this study provides reasonable estimations of annual soil loss in the Beshillo Catchment of the Blue Nile Basin, which is useful for implementing more efficient and effective SLM practices in general and planning soil conservation measures in particular. The study revealed that the lower and the top parts of the watershed, where cultivation on steep slopes has become the common practices, have the highest erosion prone areas.

The analysis also signifies that soil erosion rate estimated on the watershed matches well with the community perceptions for the study watershed suggesting farmer's broad knowledge to identify soil erosion problems, indicators, and causes for soil erosion in their locality. Their perceptions fairly agree with those apparent in the soil erosion literatures. Therefore, tackling soil erosion requires the integration of farmers' knowledge and experience on their localities rather than prescribing solutions, which farmers may not view as feasible and important.

Finally, the study demonstrated that linking RUSLE with GIS and remote sensing data are vital approaches to better estimate soil loss values, identify and delineate erosion prone areas, and prioritize the areas for effective planning of sustainable land management based on erosion severity levels in the watersheds. Nevertheless, it is imperative to remind that the estimated soil loss values might not be completely free from errors because of the inherent limitations of the model (Morgan 2005).

\section{Limitations of study and the need for future research}

The RUSLE model do not directly account for gully erosion. Hence, for a more inclusive record of the erosion hazard, identification and measurement of gullies in the watershed should be carried out to improve the accuracy of soil loss estimation for better conservation practices, planning and management in the future. Moreover, sensitivity analyses were not conducted to single out the most sensitive input parameters that guide selective and targeted interventions (Diwediga et al. 2018). 
In addition, further assessment of the soil loss impact on agricultural productivity and its impact on rural livelihoods should be carried out to establish the linkage between soil loss and unsustainable soil management practices. Moreover, since perceptions of community might be subjective, it could not fully appreciate the quantitative aspects of modeling outputs. These limitations suggest the need for further studies to generate comprehensive evidences for proper decisions.

\section{Additional file}

Additional file 1. Plates indicating soil erosion severity.

\section{Abbreviations}

DEM: digital elevation model; FAO: Food and Agricultural Organization; ha: hectare; LULC: land use and land cover; RUSLE: revised soil loss equation; TWARDO: Tenta Wereda Agriculture and Rural Development Office; SCRP: Soil Conservation Research Program; SWC: soil and water conservation; yr: year.

\section{Acknowledgements}

The authors would like to acknowledge Dilla University and University of South Africa for their support in this research project. Our heartfelt appreciation and thanks are extended to the people of the watershed for their kindness and cooperation in sharing their experiences. Finally, we would like to extend our sincere thank to Tenta district Agriculture and Administrative office members for providing valuable information and logistic arrangements during the field work.

\section{Authors' contributions}

AYY has led the overall activities of the research process such as the design of the research, data compilation, data entry and processing, data analysis, and interpretation of results as well as writing up of the manuscript. ABD has involved in improving the manuscript by providing constructive quidance, critical comments and suggestions pertaining to methodological design, data analysis, interpretation and structuring of the manuscript. Both authors read and approved the final manuscript.

\section{Funding}

No funding was received.

\section{Availability of relevant data and materials}

All the required data collected for analysis are included in the manuscript. If the datasets used in the manuscript are not clear, the corresponding author is ready to clarify and even to send the data on request.

\section{Ethics approval and consent to participate}

An attempt was made to conduct the research in an ethical manner. Prior to commencing research activities, a research site permission letter was obtained from district level concerned institutions. Since most farmers were not read written consent forms, oral consent was obtained from all participants prior to commencing the interview and discussion. Hence, as the researcher, the Authors take full responsibility for all the contents and any mistakes here in the document.

\section{Consent for publication}

We all have agreed to submit our final manuscript for Environmental Systems Research journal and approved the submission.

\section{Competing interests}

The authors declare that they have no competing interests.

Received: 23 November 2018 Accepted: 4 May 2019

Published online: 17 May 2019

\section{References}

Abate S (2011) Estimating soil loss rates for soil conservation planning in the Borena woreda of South Wollo highlands, Ethiopia. J Sustain Dev Afr 13(3):87-106

Adimassu Z, Mekonnen K, Yirga C, Kessler A (2014) Effect of soil bunds on runoff, soil and nutrient losses, and crop yield in the central highlands of Ethiopia. Land Degrad Dev 25:554-564

Amare B (2007) Landscape transformation and opportunities for sustainable land management along the eastern escarpment of Wollo (EEW), Ethiopia, PhD dissertation. University of Bern, Bern

Amsalu A, de Graaff J (2006) Farmers'views of soil erosion problems and their conservation knowledge at Beressa watershed, central highlands of Ethiopia. Agric Hum Values 23:99-108

Amsalu A, Stroosnijder L, de Graaff J (2007) Long-term dynamics in land resource use and the driving forces in the Beressa watershed, highlands of Ethiopia. J Environ Manag 83(4):448-459

Angassa A (2014) Effects of grazing intensity and bush encroachment on herbaceous species and rangeland condition in southern Ethiopia. Land Degrad Dev 25:438-451

Asfaw A, Simane B, Hassen A, Bantider A (2018) Variability and time series trend analysis of rainfall and temperature in north central Ethiopia: a case study in Woleka sub-basin. Weather Clim Extrem 19:29-41

Assefa E, Hans-Rudolf B (2016) Farmers' perception of land degradation and traditional knowledge in southern Ethiopia—resilience and stability. Land Degrad Dev 27:1552-1561

Balthazar V, Vanacker V, Girma A, Poesen J, Golla G (2013) Human impact on sediment fluxes within the Blue Nile and Atbara River basins. Geomorphology 180(181):231-241

Betrie GD, Mohamed YA, Van Griensven A, Srinivasan R (2011) Sediment management modelling in the Blue Nile Basin using SWAT model. Hydrol Earth Syst Sci 15(3):807-818

Bewket W (2007) Soil and water conservation intervention with conventional technologies in northwestern highlands of Ethiopia: acceptance and adoption by farmers. Land Use Policy 24:404-416

Bewket W, Sterk G (2003) Assessment of soil erosion in cultivated fields using a survey methodology for rills in the Chemoga watershed, Ethiopia. Agric Ecosyst Environ 97:81-93. https://doi.org/10.1016/S0167-8809(03)00127 $-0$

Bewket W, Teferi E (2009) Assessment of soil erosion hazard and prioritization for treatment at the watershed level: case study in the Chemoga watershed, Blue Nile Basin, Ethiopia. Land Degrad Dev 20:609-622. https //doi.org/10.1002/ldr.944

Brady NC, Weil RC (2012) The nature and properties of soils. Pearson Education, New Delhi

Dikau R (1989) The application of a digital relief model to landform analysis in geomorphology. In: Raper J (ed) Three dimensional application in geographic information systems. Taylor and Francis, London, pp 51-77

Diwediga B, Bao LQ, Agodzo SK, Tamene LD, Wala K (2018) Modelling soil erosion response to sustainable landscape management scenarios in the Mo River Basin (Togo, West Africa). Sci Total Environ 625:1309-1320

Erkossa T, Wudneh A, Desalegn B, Taye G (2015) Linking soil erosion to on-site financial cost: lessons from watersheds in the Blue Nile basin. Solid Earth 6:765-774

Eweg HPA, Van Lammeren R (1996) The application of a geographical information system to the rehabilitation of degraded and degrading areas. A case study in the highlands of Tigray, Ethiopia, Centre for Geographical Information Processing, Wageningen Agricultural University, Wageningen

Eweg HPA, van Lammeren R, Deurloo H, Woldu Z (1998) Analyzing degradation and rehabilitation for sustainable land management in the highlands of Ethiopia. Land Degrad Dev 9(6):529-542. https://doi.org/10.1002/ (sici) 1099-145x(199811/12)9:6\%3c529:aid-Idr313\%3e3.0.co;2-o

FAO (1986) Ethiopian highlands reclamation study, Ethiopia. Final Report. FAO, Rome

FAO (2006) Guidelines for soil description. FAO, Rome

Farhan Y, Nawaiseh S (2015) Spatial assessment of soil erosion risk using RUSLE and GIS techniques. Environ Earth Sci 74:4649-4669

Farhan Y, Zregat D, Farhan I (2013) Spatial estimation of soil erosion risk using RUSLE approach, RS, and GIS techniques: a case study of Kufranja watershed, Northern Jordan. J Water Resour Prot 5(12):1247-1261

Fenta AA, Yasuda H, Shimizu K, Nigussie H, Negussie A (2016) Dynamics of soil erosion as influenced by watershed management practices: a case study 
of the Agula watershed in the semi-arid highlands of northern Ethiopia. Environ Manag 58:889-905

Foster GR, Yoder DC, Weesies GA, McCool DK, McGregor KC, Bringer RL (2002) User's guide-revised universal soil loss equation version 2 (RUSLE 2). USDA-Agricultural Research Services, Washington, DC

Ganasri BP, Ramesh H (2016) Assessment of soil erosion by RUSLE model using remote sensing and GIS - a case study of Nethravathi Basin. Geosci Front 7(6):953-961. https://doi.org/10.1016/j.gsf.2015.10.007

Gashaw T, Tulu T, Argaw M (2017) Erosion risk assessment for prioritization of conservation measures in Geleda watershed, Blue Nile basin, Ethiopia. Environ Syst Res. https://doi.org/10.1186/s40068-016-0078-x

Gebrehiwot SG, Bewket W, Gärdenäs Al, Bishop K (2014) Forest covers change over four decades in the Blue Nile Basin, Ethiopia: comparison of three watersheds. Reg Environ Change 14(1):253-266

Gebremichael A, Yakob G, Mekonnen G (2015) Assessment of farmers' perception and adaptation mechanism to soil erosion problem in ShombaKichib, Gimbo District, Kaffa Zone, South West Ethiopia. Afr J Agric Res 10(27):2608-2616

Gelagay HS (2016) RUSLE and SDR model based sediment yield assessment in a GIS and remote sensing environment; a case study of Koga watershed, Upper Blue Nile Basin, Ethiopia. Hydrol Curr Res 7:239. https://doi. org/10.4172/2157-7587.1000239

Gelagay HS, Minale AS (2016) Soil loss estimation using GIS and remote sensing techniques: a case of Koga watershed, Northwestern Ethiopia. Int Soil Water Conserv Res 4:126-136

Gessesse B, Bewket W, Bräuning A (2015) Model-based characterization and monitoring of runoff and soil erosion in response to land use/land cover changes in the Modjo watershed, Ethiopia. Land Degrad Dev 26:711-724

Gessesse B, Bewket W, Bräuning A (2016) Determinants of farmers' tree planting investment decisions as a degraded landscape management strategy in the central highlands of Ethiopia. Solid Earth 7:639-650. https://doi. org/10.5194/se-7-639-2016

Gete Z (2000) Landscape dynamics and soil erosion process modeling in the North-Western Ethiopian highlands. African Studies Series A16. Geographica Bernensia, Berne

Haregeweyn N, Poesen J, Deckers J, Nyssen J, Haile M, Govers G (2008) Assessment and evaluation of sediment-bound nutrient export and associated costs from micro-dam catchments of Northern Ethiopia. Land Degrad Dev 19:136-152

Haregeweyn N, Poesen J, Verstraeten G, Govers G, Vente J (2013) Assessing the performance of a spatially distributed soil erosion and sediment delivery model in Northern Ethiopia. Land Degrad Dev 24(2):188-204

Haregeweyn N, Tsunekawa A, Nyssen J, Tsubo M, Meshesha DT, Schutt B, Adgo E, Tegegne F (2015) Soil erosion and conservation in Ethiopia: a review. Prog Phys Geogr 39(6):750-774

Haregeweyn N, Tsunekawa A, Poesen J, Tsubo M, Meshesha DT, Fenta AA, Nyssen J, Adgo E (2017) Comprehensive assessment of soil erosion risk for better land use planning in river basins: case study of the Upper Blue Nile River. Sci Total Environ 574:95-108

Heberlein TA (1972) The land ethic realized: some social psychological explanations for changing environmental attitudes. J Soc Issues 28(4):79-87. https://doi.org/10.1111/j.1540-4560.1972.tb00047

Hurni H (1983) Soil formation rates in Ethiopia. Ethiopian highlands reclamation study. Soil Conservation Research Project, FAO, UTF/ETH/037/ETH Working Paper 2

Hurni H (1985) Erosion-productivity-conservation systems in Ethiopia. In: Proceedings 4th international conference on soil conservation, Maracay, Venezuela, pp 654-674

Hurni H (1986) Guidelines for development agents on soil conservation in Ethiopia soil conservation research project. Community Forests and Soil Conservation Development Department, Ministry of Agriculture, Addis Ababa

Hurni H (1988) Degradation and conservation of the resources in the Ethiopian highlands. Mt Res Dev 8:123-130

Hurni H (1993) Land degradation, famine, and land resource scenarios in Ethiopia. In: Pimentel D (ed) World soil erosion and conservation. Cambridge University Press, Cambridge, pp 27-62

Hurni H (1996) Precious earth: from soil and water conservation to sustainable land management. International Soil Conservation Organization (ISCO) and Center for Development and Environment (CDE), Berne, Switzerland
Hurni $\mathrm{H}$ (2002) Current international actions for furthering the sustainability use of soils. In: Symposium paper no. 63 on 17th WCSS, 14-21 August 2002, pp 8

Karltun E, Lemenih M, Tolera M (2013) Comparing farmers' perception of soil fertility change with soil properties and crop performances in Beseku, Ethiopia. Land Degrad Dev 24:228-235. https://doi.org/10.1002/ldr.1118

Kouli M, Soupios P, Vallianatos F (2009) Soil erosion prediction using the Revised Universal Soil Loss Equation (RUSLE) in a GIS framework, Chania, Northwestern Crete, Greece. Environ Geol 57:483-497

Lal R (1990) Soil erosion in the tropics: principles and management. McGraw Hill, New York

Lal R (1994) Soil erosion by wind and water: problems and prospects. In: Lal R (ed) Soil erosion research methods, 2nd edn. Soil and Water Conservation Society, St. Lucie Press, Ankeny, pp 1-9

Lal R (2001) Soil degradation by erosion. Land Degrad Dev 12:519-539. https ://doi.org/10.1002/ldr.472

Li J, Heap AD (2008) A review of spatial interpolation methods for environmental scientists. Geoscience Australia 2008/2003

Mekonnen M, Keesstra SD, Baartman JE, Ritsema CJ, Melesse AM (2015) Evaluating sediment storage dams: structural off-site sediment trapping measures in northwest Ethiopia. Cuadernos de Investigación Geográfica 41:16. https://doi.org/10.18172/cig.2643

Mengistu D, Bewket W, Lal R (2013) Recent spatiotemporal temperature and rainfall variability and trends over the upper Blue Nile River basin, Ethiopia. Int J Climatol 34:2278-2292

Meshesha DT, Abele S (2016) Determinants of small-scale farmers' perceived soil erosion severity: a plot-level analysis from Ethiopia. Land Degradation and Development submitted after revision

Meshesha DT, Tsunekawa A, Tsubo M, Haregeweyn N (2012) Dynamics and hotspots of soil erosion and management scenarios of the central Rift Valley of Ethiopia. Int J Sediment Res 27(1):84-99

Millward A, Mersey JE (1999) Adapting the RUSLE to model soil erosion potential in a mountainous tropical watershed. CATENA 38:109-129

Ministry of Agriculture (MOA) (1998) Agroecological Zones of Ethiopia. MOA, Addis Ababa

Ministry of Water Resources of Ethiopia (MoW) (1998) Abbay river basin integrated development master plan, main report. Ministry of Water Resources, Addis Ababa

Mitasova H, Mitas Z (1999) Modeling soil detachment with RUSLE 3D using GIS. University of Illinois at Urbana champaign, Champaign

Monsieurs E, Dessie M, Adgo E (2015) Seasonal surface drainage of sloping farmland: a review of its hydrogeomorphic impacts. Land Degrad Dev 26(1):35-44

Moore ID, Burch GJ (1986) Physical basis of the length-slope factor in the universal soil loss equation. Soil Sci Soc Am J 50(5):1294-1298

Moore D, Wilson JP (1992) Length slope factor for the revised universal soil loss equation: simplified method of solution. J Soil Water Conserv 47(5):423-428

Morgan RPC (1995) Soil erosion and conservation, 2nd edn. Longman, Essex

Morgan RPC (2005) Soil erosion and conservation, 3rd edn. Blackwell Publishing, Oxford

Nigussie Z, Tsunekawa A, Haregeweyn H, Adgo E, Nohmie M, Tsubo M, Aklog D, Meshesha DT, Abele S (2016) Determinants of small-scale farmers' perceived soil erosion severity: a plot-level analysis from Ethiopia. Land Degradation and Development submitted after revision

Nyssen J, Poesen J, Moeyersons J, Deckers J, Haile M, Lang A (2004) Human impact on the environment in the Ethiopian and Eritrean highlands-a state of the art. Earth Sci Rev 64(3-4):273-320

Nyssen J, Vandenreyken H, Poesen J (2005) Rainfall erosivity and variability in the Northern Ethiopian highlands. J Hydrol 311:172-187

Nyssen J, Poesen J, Mitiku H, Moeyersons J, Deckers J, Hurni H (2009) Effects of land use and land cover on sheet and rill erosion rates in the Tigray highlands, Ethiopia. Zeitschrift für Geomorphologie 53(2):171-197

Oldeman L, Van Lynden G, Van Engelen V (1995) An international methodology for soil degradation assessment and for a soils and terrain digital database (SOTER). In: Paper presented at the regional workshop on assessment and monitoring of land degradation, Cairo, May 13-15, 1995

Oliveira PTS, Rodrigues DBB, AlvesSobrinho T, Panachuki E, Wendland E (2013) Use of SRTM data to calculate the (R)USLE topographic factor. Acta Scientiarum Technology 15:507-513 
Panagos P, Borrelli P, Meusburgerb K, van der Zanden E, Poesen J, Alewell $C$ (2015) Modeling the effect of support practices (P-factor) on the reduction of soil erosion by water at European scale. Environ Sci Policy 51:23-34

Piccarreta M, Capolongo D, Boenzi F, Bentivenga M (2006) Implications of decadal changes in precipitation and land use policy to soil erosion in Basil-icata, Italy. CATENA 65:138-151

Pimentel D (2006) Soil erosion: a food and environmental threat. Environ Dev Sustain 8(1):119-137

Poesen JW, Torri D, Bunte K (1994) Effects of rock fragments on soil erosion by water at different spatial scales: a review. CATENA 23(1-2):141-166

Prasannakumar V, Vijith H, Abinod S, Geetha N (2012) Estimation of soil erosion risk within a small mountainous sub-watershed in Kerala, India, using revised universal soil loss equation (RUSLE) and geo-information technology. Geosci Front 3:209-215

Renard KG, Foster GR, Weesies GA, Porter JP (1991) RUSLE: revised universal soil loss equation. J Soil Water Conserv 46(1):30-33

Renard KG, Foster GR, Weesies GA, McCool DK, Yoder DC (1997) Predicting soil erosion by water: a guide to conservation planning with the revised universal soil loss equation (RUSLE). Agriculture Handbook No. 703, USAD-ARS, Washington

Rodrigo CJ, Brings C, Lassu T, Iserloh T, Senciales JM, Martínez MJF, Ruiz SJD, Seeger M, Ries JB (2015) Rainfall and human activity impacts on soil losses and rill erosion in vineyards (Ruwer Valley, Germany). Solid Earth 6:823-837

Romkens MJM, Young RA, Poesen JWA, McCool DK, El-Swaify SA, Bradford JM (1997) Soil erodibility factor (K). In: Renard KG, Foster GR, Weesies GA, McCool DK, Yoder DC (eds) Predicting soil erosion by water: a guide to conservation planning with the revised universal soil loss equation (RUSLE). U.S. Government Printing Office, Washington, DC, pp 65-100

Rose CW (1994) Research on soil erosion processes and a basis for soil conservation practices. In: Soil erosion research methods. Columbus, pp 179-181

Simms AD, Woodroffe CD, Jones BG (2003) Application of RUSLE for erosion management in a coastal catchment, Southern NSW. In: Proceedings of the international congress on modeling and simulation: integrative

Soil Conservation Research Project (SCRP) (1996) Soil erosion hazard assessment for land evaluation. Research report. SCRP, Addis Ababa

Sonneveld B, Keyzer MA (2003) Land under pressure: soil conservation concerns and opportunities for Ethiopia. Land Degrad Dev 14(1):5-23

Tamene L, Vlek PL (2008) Soil erosion studies in Northern Ethiopia. Center for Development Research, University of Bonn, Bonn

Tamene L, Abegaz A, Aynekulu A, Woldearegay K, Vlek PLG (2011) Estimating sediment yield risk of reservoirs in northern Ethiopia using expert knowledge and semi-quantitative approaches. Lakes Reserv Res Manag 16:293-305

Tamene L, Le QB, Vlek PLG (2014) A landscape planning and management tool for land and water resources management: an example application in Northern Ethiopia. Water Resour Manag 28:407-424

Tamene L, Adimassu Z, Aynekulu E, Yaekob T (2017) Estimating landscape susceptibility to soil erosion using a GIS-based approach in Northern Ethiopia. Int Soil Water Conserv Res 5(3):221-230. https://doi.org/10.1016/j. iswcr.2017.05.002

Tebebu TY, Abiy AZ, Zegeye AD, Dahlke HE, Easton ZM, Tilahun SA, Collick AS, Kidanu S, Moges S, Dadgar F, Steenhuis TS (2010) Surface and sub-surface flow effect on permanent gully formation and upland erosion near Lake Tana in the northern highlands of Ethiopia. Hydrol Earth Syst Sci 14:2207-2217

Tefera B, Sterk G (2010) Land management, erosion problems and soil and water conservation in Fincha'a watershed, western Ethiopia. Land Use Policy 27:1027-1037. https://doi.org/10.1016/j.landusepol.2010.01.005

Tully K, Sullivan C, Weil R, Sanchez P (2015) The state of soil degradation in sub-saharan Africa: baselines, trajectories, and solutions. Sustainability 7(6):6523-6552. https://doi.org/10.3390/su7066523

TWARDO (2017) Tenta Wereda Agriculture and Rural Development Office, Adjibar

Weldemariam D, Kebede M, Taddesse M, Gebre T (2013) Farmers perceptions and participation on mechanical soil and water conservation techniques in Kembata Tembaro Zone: the case of Kachabirra Woreda, Ethiopia. Adv Struct Geotech Eng J 2:118-131

Wischmeier WH, Smith DD (1978) Predicting rainfall erosion losses. A guide to conservation planning. US Department of Agriculture, Agriculture Handbook, vol. 537, Washington DC, pp 85

Woldemariam GW, Iguala AD, Tekalign S, Reddy RU (2017) Spatial modeling of soil erosion risk and its implication for conservation planning: the case of the Gobele Watershed, East Hararghe Zone, Ethiopia. Land 7(25):78. https ://doi.org/10.3390/land7010025

Wolka K, Tadesse H, Garedew E, Yimer F (2015) Soil erosion risk assessment in the Chaleleka wetland watershed, Central Rift Valley of Ethiopia, Environmental Systems Research, pp 45

Yihenew G, Yihenew B (2013) Costs of nutrient losses in priceless soils eroded from the highlands of Northwestern Ethiopia. J Agric Sci 5(7):1916-9752

\section{Publisher's Note}

Springer Nature remains neutral with regard to jurisdictional claims in published maps and institutional affiliations.

\section{Submit your manuscript to a SpringerOpen ${ }^{\circ}$ journal and benefit from:}

- Convenient online submission

- Rigorous peer review

- Open access: articles freely available online

- High visibility within the field

Retaining the copyright to your article

Submit your next manuscript at springeropen.com 